\title{
INFLATION TARGETS VERSUS INTERNATIONAL MONETARY INTEGRATION - A CANADIAN PERSPECTIVE
}

\author{
DAVID LAIDLER \\ CESIFO WORKING PAPER NO. 773 \\ CATEgORY 6: MONETARY POLICY AND InTERNATIONAL FinANCE \\ SEPTEMBER 2002 \\ An electronic version of the paper may be downloaded \\ - from the SSRN website: www.SSRN.com \\ - from the CESifo website: www.CESifo.de
}




\title{
INFLATION TARGETS VERSUS INTERNATIONAL MONETARY INTEGRATION - A CANADIAN PERSPECTIVE
}

\begin{abstract}
The debate about Canadian-U.S. monetary integration is surveyed. The choice is among overall monetary orders,rather than exchange rate regimes and questions of policy credibility and political accountability are crucial. Canada's recent economic performance under inflation targets, and arguments that the flexible exchange rate has undermined real economic performance are assessed. The most economically attractive among alternative monetary orders, the adoption by Canada of the US dollar with provision for meaningful Canadian input into policy decisions and supervision of the financial system - is not politically attainable. Intermediate arrangements are unattractive and clearly inferior to Canada's current monetary order.
\end{abstract}

JEL Classification: E42, E52, E58, F33.

Keywords: monetary policy, exchange rates, central banks, inflation.

David Laidler

Department of Economics, SSC

University of Western Ontario

London, Ontario N6A 5C2

Canada

laidler@uwo.ca 


\section{Introduction $^{1}$}

To say that the world's monetary system is in a state of constant evolution is platitudinous, but true. At the moment, international monetary arrangements seem to veering towards two extremes: national currencies supported by exchange rate flexibility, or extremely hard fixes, of which monetary integration across national boundaries is the limiting case. In the post-World War II period, Canada has been the most steadfast of floaters, having "temporarily" abandoned its Bretton Woods peg to the US dollar in 1950, and having returned to a fixed rate only once for a little under ten years (1962-70) in the interim. But even Canada is open to change, and for the last few years, particularly since the international financial upheavals of 1997-98, there has been an ongoing local debate about whether the country would be better off with some sort of fixed exchange rate on the United States dollar, and more specifically, as that debate has evolved, the adoption of a common North American a common currency has emerged as the alternative of choice to the status quo. ${ }^{2}$

This paper provides an overview of the debate in question, and a defence of Canada's current monetary arrangements. The following pages first establish a framework for discussion by arguing that, in dealing with the issues at stake here, one needs to consider a country's overall monetary order, including its political aspects, rather than the exchange rate regime in isolation. Then Canada's current inflation-targeting monetary order and the economy's performance since its inception in 1991 are discussed. A survey of the forms that North American monetary integration might feasibly take leads to the conclusion that the degree of US hegemony over Canadian affairs that is implicit in any monetary arrangement to which the US might be willing to be party presents a serious political deterrent to Canada's pursuing such a goal, and that, given the satisfactory performance of the current monetary order, it should be kept in place.

\section{A Framework for Discussion: The Monetary Order}

All national economies use money and are open, and yet economists have often broken the discussion of their monetary arrangements into self-contained segments to be discussed in isolation from one another. Thus, when domestic matters have been the centre of attention, they have discussed such topics as rules versus authorities, real versus various nominal targets for monetary policy, and within the latter grouping they have debated the relative merits of money growth, nominal GDP growth, and inflation. When the design of central banks has been on the agenda, they have analysed goal and instrument independence, not to mention interest rate and base control as alternative means of implementing monetary policy. And when specifically international matters have been in the forefront, they have talked, among other things, about fixed versus crawling versus flexible exchange rates, with

\footnotetext{
${ }^{1}$ The author is Bank of Montreal Professor at the University of Western Ontario, London, Ontario, and Canadian Bankers' Association Scholar and Fellow-in-Residence at the C. D. Howe Institute, Toronto, Ontario. An earlier version of this paper was presented at the European Central Bank on February 25, 2002 and he is grateful for the helpful comments received on that occasion. He also thanks Shay Aba, Finn Poschmann and Bill Robson for innumerable conversations on this topic, and the last-named as well as Peter Howitt, Clark Leith, Hans-Michael Trautwein and Geoffrey Wood for comments on an earlier draft. The help of Otto Reich, who collected data and prepared the charts is also gratefully acknowledged.

${ }^{2}$ Among early contributions to this debate are Courchene and Harris (1999a), Grubel (1999), Laidler (1999), Orr (1999) and von Furstenberg (2000).
} 
and without policy co-ordination, and so on.

Now to break a topic down into manageable portions has its uses, but it has its perils too, for it is easy to lose sight of the inter-connectedness of topics, and to fail to notice that conclusions reached about one area have implications for others. In the monetary policy field this has sometimes happened, and that is why the first substantive step in this paper must be to establish a framework for the discussion that recognises the interconnectedness of the components of what I like to call the monetary order. ${ }^{3}$

It is helpful to think of such an order as consisting of four components:

(i) The goals of monetary policy;

(ii) The institutional background and broader policy framework within which these goals are pursued;

(iii) The credibility of those same goals among the public at large, and hence the compatibility of their beliefs and actions with those goals;

(iv) The political institutions through which decisions about the first two components of the monetary order are taken, and the extent to which they provide for public accountability on the part of those making and executing those decisions.

With matters put this way, it is readily seen that it is all too easy for dissonances to arise within any country's monetary order which can lead to malfunctions. A monetary order may be incoherent for many reasons, and fail to achieve its goals. For example, problems can be created by assigning the twin goals of "full employment" and "price stability" to a monetary authority, and then giving specific empirical content to them that renders them unattainable as a consequence of, say, policies that are simultaneously being implemented towards the structure of the labour market. Or, to cite another common failing, the credibility of a low inflation or fixed exchange rate goal can be undermined by irresponsible fiscal policies. A flawed monetary order will not maintain, or even perhaps achieve, credibility, and in due course, it will lose the political support needed to keep it in place. ${ }^{4}$

Furthermore, it is not hard to see how a country's political history and institutions can influence the extent to which the population at large trusts the monetary authorities to begin with, and expects to be able to hold them accountable on an ongoing basis through mechanisms that the current institutional framework, itself a creation of a specific history, provides. Such factors explain why, for example, the electorates of European countries that have ratified the Maastricht Treaty, one of whose elements was the establishment of a new currency, the Euro, under the auspices of a European Central Bank that is virtually independent of the domestic politics of individual countries, are in a very different position vis-a-vis their monetary authorities than the electorate of the United States. There the central bank draws its authority from the Federal Reserve Act, must abide by the Humphrey Hawkins Act, and defines itself as independent within rather than of the federal government.

More generally, these factors also explain why the politics of monetary policy are likely to play themselves

\footnotetext{
${ }^{3}$ I prefer this time honoured phrase to the more commonly used but narrower "monetary policy regime" since it more naturally encompasses the attitudes of the general public towards monetary policy, including their expectations about its outcome.

${ }^{4}$ Heymann and Leijonhufvud (1995) particularly stress this factor as underlying the breakdown of stabilisation programs in their study of High Inflation.
} 
out in very different ways in different jurisdictions. Again, a comparison of Europe and North America is instructive. As Lars Jonung (2002) has recently argued, for Sweden and the United Kingdom, the two members of the European Union that still maintain a flexible exchange rate against the Euro, the main political element in the decision whether or not to give up their own currencies has to do with differing degrees of trust that their electorates put in domestic versus European institutions, either of which would nevertheless be accountable to them. In North America on the other hand, as will be shown below, the major political choice facing the Canadian electorate is whether to continue with Canadian policy making institutions that are domestically accountable, or to surrender control of important aspects of economic policy to American institutions that would remain accountable only to the US electorate.

There is, then, no single monetary order that is uniquely coherent, nor is there any particular reason to suppose that, among those that are economically viable in principle, the same style of monetary order will turn out to be politically acceptable, or even workable, in every country. To pose the fundamental choice in monetary matters as being among alternative orders, therefore, draws attention to certain pitfalls in more partial approaches, not least, and perhaps particularly, those which deal with to exchange rate arrangements in isolation. Even the traditional question "fixed or flexible exchange rates?" turns out to be badly formulated when viewed in this light.

A fixed exchange rate is, in and of itself, a goal for monetary policy, and because the exchange rate is clearly visible to economic agents in general, and a variable of considerable importance too, a fixed value for it may be a credible policy goal, and one for whose achievement the authorities can be held politically accountable. To argue for a fixed exchange rate, then, is to argue for an arrangement that in and of itself comes close to characterising a coherent monetary order because it impinges directly on three of its four defining components. A flexible exchange rate, on the other hand, is merely an institutional arrangement that falls under heading (ii) above. Its adoption does not define a policy goal, but merely permits some other goal, or goals, attainable or not, to be pursued. It is only when these have been specified that a discussion of the viability of a monetary order, one of whose components is a flexible exchange rate, can begin. It is small wonder, then, that when faced with a choice between "fixed" or "flexible" exchange rates in isolation, most people select "fixed". The alternative all too often seems synonymous with "anything goes", and who would choose that in monetary affairs?

To think in terms of the monetary order, rather than of the exchange rate regime itself, is useful in other ways too. For example, an adjustable peg regime, viewed in this light, appears as a monetary order under which a fixed value for the exchange rate is the single target of monetary policy, but only for so long as the monetary authorities do not find some other goal more pressing. The difficulties that such arrangements have had in practice in establishing credibility, and hence their proneness to speculative attacks, are not hard to understand when matters are put this way. And more sophisticated proposals for exchange rate arrangements also present problems which can be easily elucidated when they are placed in this broader context. "Crawling pegs" or "target zones" are, for example, typically proposed because they permit the monetary authorities simultaneously to attend to other matters. Until these other matters are specified, however, and their interconnectedness to the exchange rate analysed, it is impossible to say anything about the viability of the monetary order of which the exchange rate regime in question is to form a part. And if these interconnections are complicated, then even when a proposed 
monetary order of this sort is logically coherent, its complexity may well create difficulties when it comes to generating credibility and political support for it. ${ }^{5}$ The framework provided by the idea of a monetary order forces one to confront these difficulties.

Now, in practice, flexible exchange rates have sometimes been associated with some very odd policy goals indeed, in Canada as much as elsewhere, and their pursuit has implied monetary orders that have been incoherent, or if coherent, incapable of establishing credibility, and hence unsustainable. There is no need here to discuss these matters in detail. Suffice it to assert that a flexible exchange rate does not inevitably create such problems. In particular, Canada's current monetary order is based on clearly stated inflation targets and is supported by fiscal policy that is compatible with their continued pursuit. Furthermore, the general public understands what the inflation rate is and why it is important, and this understanding in turn provides an important precondition for the credibility of monetary policy, and for the electorate's ability to hold policy makers accountable for their performance.

In short, the choice now being debated in Canada is not between maintaining a flexible exchange rate or going to some sort of hard-fix arrangement vis-a-vis the US dollar, though the matter is often stated this way. Rather, it lies among maintaining a rather recently established but coherent monetary order based on inflation targets for a separate national currency, whose exchange rate against other currencies is market determined, and a number of alternatives, all involving one degree or another of North American monetary integration. The first step in evaluating this choice must be to describe the current order in more detail, and then to assess the economy's performance in its presence.

\section{Canada's Current Monetary Order}

In Canada at the moment, the precise goal of monetary policy is the maintenance of an inflation rate as measured by the consumer price index that fluctuates around 2 per cent. per annum, while remaining in a $1-3$ per cent range. This goal has been jointly set by the Minister of Finance on behalf of Parliament, and the Bank of Canada, so the latter institution clearly does not enjoy anything approaching what Stanley Fischer (1995) has called "goal independence". It is also worth noting that, though the inflation target clearly defines a mandate for the Bank of Canada, it is not written into its governing legislation. ${ }^{6}$

Inflation targets have been in place since 1991, with only minor modifications, and, as Figure 1 shows, the

\footnotetext{
${ }^{5}$ Indeed, I suspect that the rapidly growing preference for monetary orders involving simple goals, such as an inflation target or a rigidly fixed exchange rate, largely stems from these latter considerations. After all, as far as the logic of an economic system is concerned, a "single target" for monetary policy consisting of an index of inflation and the exchange rate that is compatible with the economy's structure, is logically viable, and the two extremes may be thought of as particular corner solutions to the problem of selecting such an index that are unlikely to be optimal in any usual sense. They are, however, simple and easily understood by the public at large, which as far as the politics of monetary policy is concerned, is a decisive advantage in any country where democratic accountability in such matters is taken seriously.

${ }^{6}$ This still suggests, as it did in 1934, that the Bank should ". . . regulate credit and currency in the best interests of the economic life of the nation, to protect the external value of the national monetary unit and to mitigate by its influence fluctuations in the general level of production, trade, prices and employment, so far as may be possible within the scope of monetary action, and generally to promote the economic and financial welfare of Canada."
} 
Bank of Canada has had considerable success in attaining them, particularly in the second half of the '90s. Before then, there was a marked tendency for inflation to remain in the lower half of the target range, or even to fall below its lower bound. These targets now seem to be credible, and to enjoy widespread political support too, so much so that their renewal at the end of 2000 for a further five years was completely uncontroversial among the general public.

\section{Chart 1: Quarterly Canadian Inflation Rate (at Annual Rates); 1970Q4 - 2001Q4; Source: CANSIM P100000}

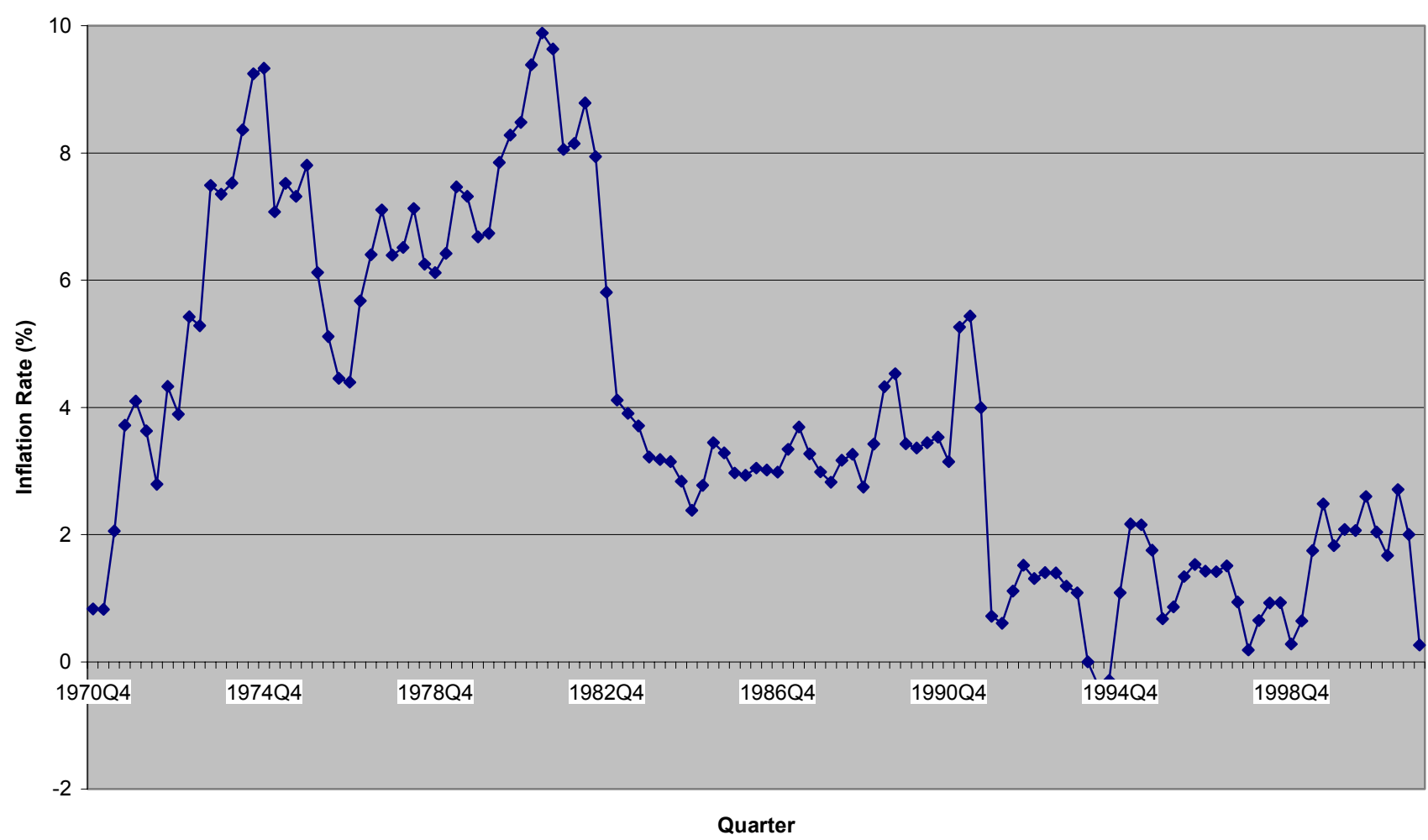

The institutional background against which inflation targets are pursued is of course complex. Suffice it here to note: that the Bank of Canada Act gives that institution all the legal authority necessary to conduct of monetary policy as it is usually understood, and to provide lender of last resort facilities to the financial sector; that, like many other central banks nowadays, the Bank of Canada relies primarily on its control of the overnight interest rate to exert influence on the economy; that, unlike many central banks, it has no regulatory authority over the banking system beyond that inherent in its role in the clearing and settlement system, these powers resting mainly with the Superintendent of Financial Institutions and the Canadian and Quebec Deposit Insurance Corporations; and that the exchange rate of the Canadian dollar is market determined, in the everyday sense of the phrase, the Bank of Canada not having intervened in the foreign exchange market since August 1998.

The Bank enjoys de facto "instrument independence" in normal times, though the nature of its corporate structure as defined by the Bank of Canada Act does put certain limits on this. The Bank is a crown corporation, with all shares being held by the Minister of Finance on behalf of the people of Canada, and its twelve directors are part time political appointees. Though they exercise no control over the conduct of policy, they are not without indirect influence. Specifically, the directors appoint both the Governor and Senior Deputy Governor, subject to 
cabinet approval, and take seriously their responsibility for overseeing the competence with which the Bank's professional staff undertakes its work. Furthermore, the Deputy Minister of Finance is a thirteenth, but non-voting, member of the Board, while the Governor is expected to consult regularly with the Minister himself regarding the conduct of policy. Even so, policy decisions are made by an informal Governing Council consisting of the Governor, the Senior Deputy Governor, and four other Deputy Governors, who are protected from day to day political pressures by two factors.

First, the appointments of the Governor and his Senior Deputy are on a "good behaviour" basis and for seven year terms; hence they can only be removed by Act of Parliament, and the timing of appointments and reappointments is desynchronized from the electoral cycle.

Second, and crucially, there is a unique local arrangement, known as dual responsibility, which came into being in the wake of the so-called Coyne affair, in which the Governor of the Bank, James Coyne was forced from office in 1961 by a government that disagreed with his policies. Under this arrangement, it is the Bank which is normally responsible for monetary policy, but, in the event of any disagreement, the Minister of Finance has final authority. He must, however, exert it by issuing and publishing a written directive to the Governor, cast in specific terms and for a specific and limited time period. This much is written into the Bank of Canada Act as it was amended in 1967. Not in the Act, but equally important, is the clear understanding, first enunciated by Coyne's successor Louis Rasminsky, as a condition of accepting the governorship, that such any directive will be read by the Governor as a request for his resignation, which will immediately be forthcoming. ${ }^{7}$

None of this means that the Bank of Canada is inclined to insulate itself from public opinion. On the contrary, "increased transparency" has been very much a watchword in recent years. ${ }^{8}$ The Bank issues an Annual Report two semi-annual Monetary Policy Reports, interspersed with two briefer up-dates, and now sets its interestrate target every six weeks, releasing a short explanation of its action (or inaction) when it does so. The Governor and his officials also appear regularly before Parliamentary Committees and give frequent lectures and speeches to interested groups. Hence the Bank's considerable degree of autonomy from day to day politics is accompanied, and indeed strengthened, by a continuous effort to explain its actions to the electorate.

Nevertheless, and crucial to the topic of this essay, the Bank of Canada has no authority over the country's choice of exchange rate arrangements. The Bank of Canada Act clearly states that it functions as the elected government's agent in the foreign exchange market. This means that, even within the current monetary order, foreign exchange market intervention can only be undertaken with the permission of the Minister of Finance. It also means that any decision to change the Canadian monetary order by fixing the exchange rate, creating a currency board, joining a currency union, or adopting the US dollar as Canada's domestic currency, is clearly and solely the responsibility of that elected government.

\footnotetext{
${ }^{7} \mathrm{~A}$ brief guide to this episode is to be found in Laidler and Robson (1993) pp. 38 et seq.

${ }^{8}$ The lectures collected together in Thiessen (2001) are the key source documenting the evolution of Bank of Canada thinking about policy transparency in the 1990s.
} 


\section{Canada's Economic Performance since 1991}

Formal inflation targets were introduced in Canada in 1991, but a shift towards making low inflation the central goal of monetary policy antedated their adoption by about three years. A notable landmark here was Governor John Crow's 1988 lecture on "The Work of Monetary Policy" in the wake of which there was much talk of a "zero inflation" goal for monetary policy. This phrase appeared in no official pronouncements of which I am aware, and, in fact, Crow set neither precise targets nor a time horizon for achieving them in $1988 .{ }^{9}$ Nor was any clarification of the Bank's intentions soon forthcoming, beyond a number of reaffirmations that "price stability" was its aim, and, from mid-1989 onwards, the implementation of a marked tightening of monetary policy.

Even this imprecise goal did not at first seem to be shared by the elected government, as for example, David Johnson (1990) and William Robson (1990), who made use of inflation forecasts embodied in the Federal Budget of that year to make their point, were quick to note. This was, inevitably, a contentious matter in a country whose central bank legislation made it clear that ultimate responsibility for monetary policy did indeed rest with the elected government. The critical question in the ensuing debate quickly became - to borrow the title of my own contribution to it - How Shall We Govern the Governor ? $^{10}$ But, presumably because a Minister of Finance, who was then presiding over a large and rapidly growing public debt and a chronic current account deficit, would not have found it expedient to provoke the resignation of a central bank Governor by publicly ordering him to implement policies which would clearly have led to higher inflation, it was the Bank's policies that prevailed over this period.

It might seem that the announcement of inflation targets in 1991, jointly agreed between the government and the Bank, reflected a strategic change of attitude towards the conduct of macroeconomic policy in general, and monetary policy in particular, on the part of elected politicians, but this was not the case. Whatever the Bank of Canada's longer term intentions might have been when inflation targets were put in place, from the point of view of the government of the day, they were introduced almost accidentally, and certainly opportunistically. 1991 was the year in which Canada's federal government replaced a hidden, and rather narrowly based, Manufacturer's Sales Tax with a highly visible and altogether more broadly based value added tax, known locally as the Goods and Services Tax (GST), and this change was widely and correctly expected to impart a once-and-for-all upward push to the measured CPI. There was a perceived threat, based on statements by trade union leaders, that this once and for all push might set in motion an upward spiral of money wages and prices, particularly in unionised sectors of the economy, and the government seems to have regarded inflation targets as a useful tool in forestalling this threat. They enabled the point to be made clearly that monetary policy could be expected to accommodate the initial

\footnotetext{
${ }^{9}$ The phrase seems to have come into common use, following the publication of a (1990) collection of essays, edited by Richard Lipsey, entitled Zero Inflation: the Goal of Price Stability but it is not clear that it was this title that originated the use of this phrase to characterise Bank of Canada policy.

${ }^{10}$ This debate culminated in the publication of a parliamentary report on The Mandate and Governance of the Bank of Canada (Canada, Parliament, 1992) commonly known as the Manley Report which recommended no changes in these matters. This Report is discussed by Laidler and Robson (1993) pp.125 et seq. Nevertheless, the Bank's own creation of an informal Governing Council, responsible for monetary policy decisions, and its increasing attention to issues of accountability and policy transparency during the 1990s should probably be seen as responses to this debate.
} 
impact of the GST on the price level, but not any second and subsequent round effects.

Not surprisingly, the mere announcement of inflation targets did not establish their credibility. It required political developments, none of which looked very likely ex ante, to make real headway here.

First, the election of a Liberal government at the end of 1993 had the widely expected consequence that John Crow, whose term as Governor was co-incidentally expiring, and whose conduct of policy had become an election issue, did not continue in office for a second term. He was replaced, however, not by one of his critics, but by the Bank's Senior Deputy Governor, Gordon Thiessen who immediately struck an agreement about inflation targets with the new government that weakened them only cosmetically. Specifically the target range of 1 - 3 per cent for inflation had, under Mr. Crow, been seen as a step along the way to "price stability", defined as an inflation rate of clearly less than 2 per cent., which was to be attained in 1995. Under Mr. Thiessen the quantitative definition of "price stability" was postponed pending further experience, and in fact the $1-3$ per cent range has now become a permanent feature of the economic landscape. ${ }^{11}$

\footnotetext{
${ }^{11}$ There is, of course, room for dissent from my own judgement that this modification has been of second-order
} importance. 
Chart 2: 90 - Day Prime Corporate Paper Rate (Canada) and 3 - Month Commercial Paper Rate

(U.S.); 1970Q1 -2001Q4 (CD), 1982Q1 - $2001 Q 4$ (U.S.); Source: IFS

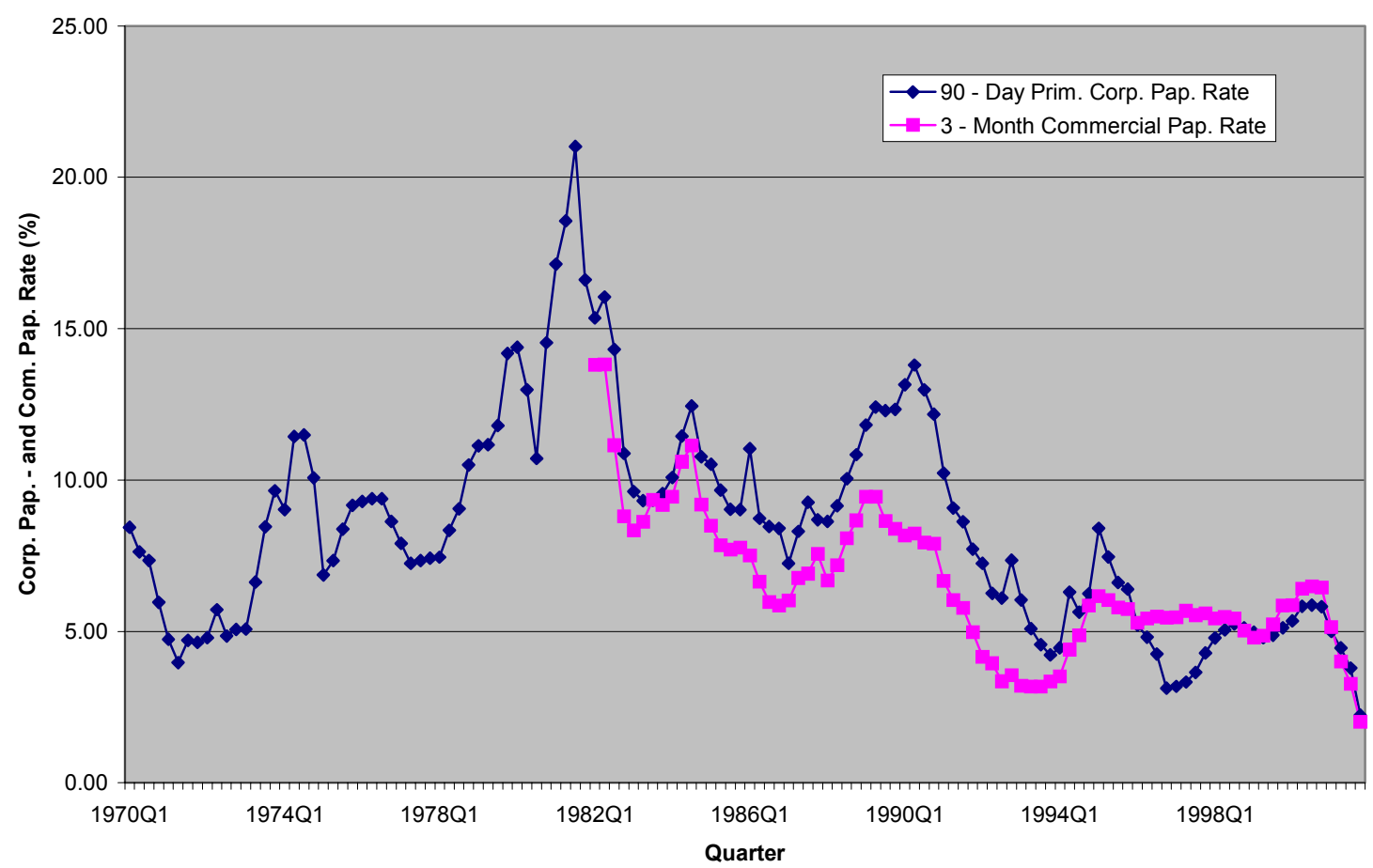

In addition to supporting inflation targets, that same new Government, having abandoned its election pledges to abolish (or "replace") the GST and to seek major revisions to the North American Free Trade Agreement, then proceeded to put in place, beginning with its 1995 budget, a fiscal regime that, three years later, brought to an end a quarter century of deficits and has produced surpluses ever since, even during the slow-down 
Chart 3: Government Bond Yield 5 -10 Year (Canada) and Government Bond Yiel 10 Year (U.S.), 1970Q1 - 2001Q4; Source: CANSIM B14011 and IFS

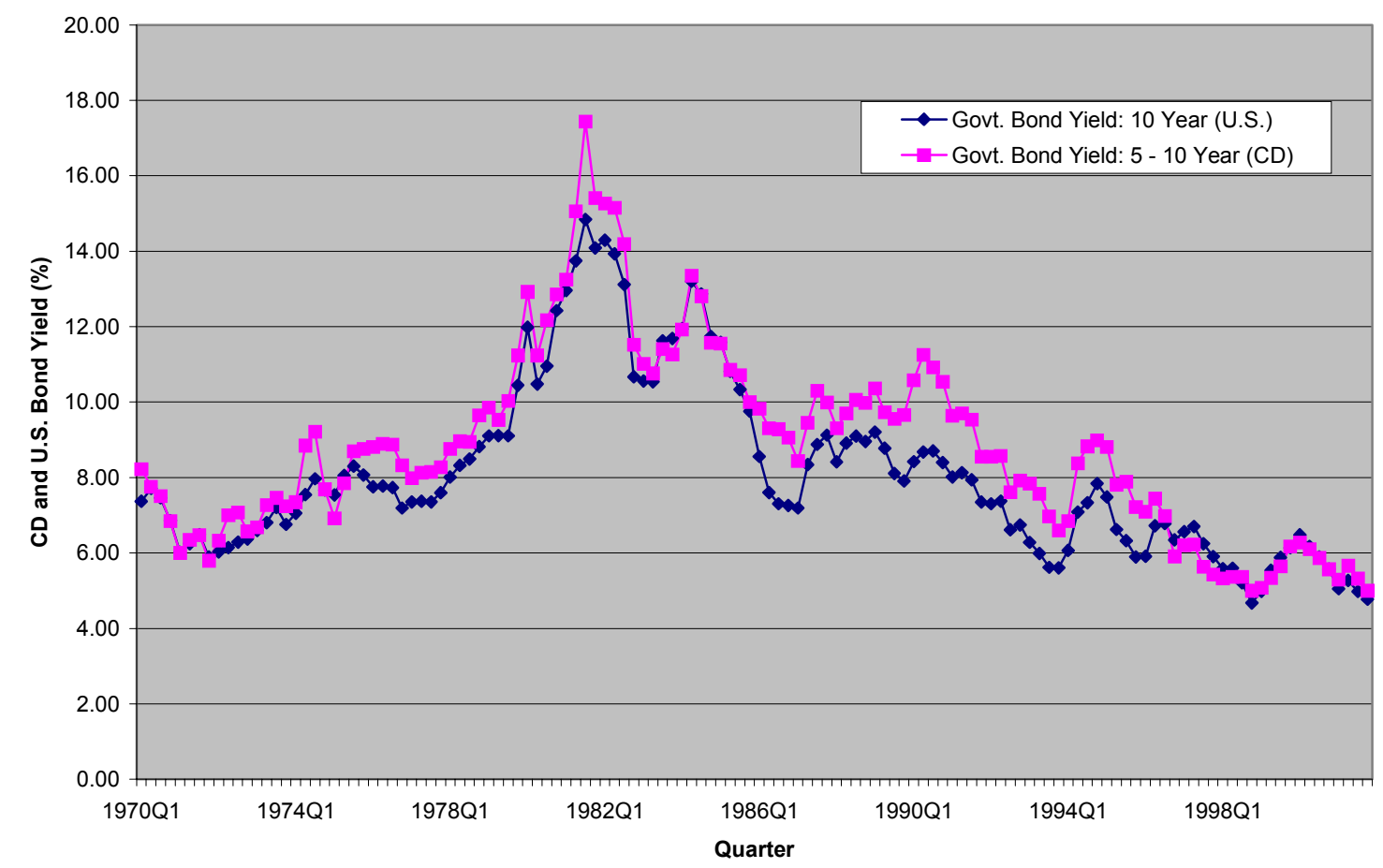

of 2001-02. The "monetarist arithmetic" that had hung over Canada's inflation targets from their inception was thus transformed from a serious threat into a strong support that no-one who had followed the 1993 election campaign could reasonably have foreseen.

Finally, it is worth reiterating that the Bank of Canada either achieved or undershot its assigned targets from the outset, and that the experience of low inflation from 1991 onwards must also have made its own contribution to the regime's credibility. Figures 2 and 3 which present data on short and long term interest rates show how these fell in Canada in the mid-1990s, and also how long-standing US-Canadian interest differentials essentially disappeared at that time.

Though Canada's inflation targets have been in place for a decade, then, the creation of the broader policy framework necessary to establish their credibility and to create political support for them was an altogether slower process, and it would be wrong to think of the current monetary order having been firmly in place before about 1995. This in turn makes the experience of the second half of the 1990s particularly relevant to assessing that order's performance, and the accompanying charts should be read with this in mind. They show that, compared to the previous two decades, the period of inflation targeting in Canada has been one of immense improvement in economic performance: inflation has fallen and then remained low (Chart 1), as have nominal interest rates (Charts 2 and 3); real output growth has increased (Chart 4) and unemployment fallen (Chart 5), particularly towards the end of the decade, while the government debt to GDP ratio, particularly at the federal level, has fallen dramatically (Chart 6), as has the net foreign debt to GDP ratio.(Chart 7). 
Chart 4: Quarterly Canadian Real Growth Rate (GDP) at Annual Rates; 1971Q1 - 2001Q4; Source: CANSIM D100525

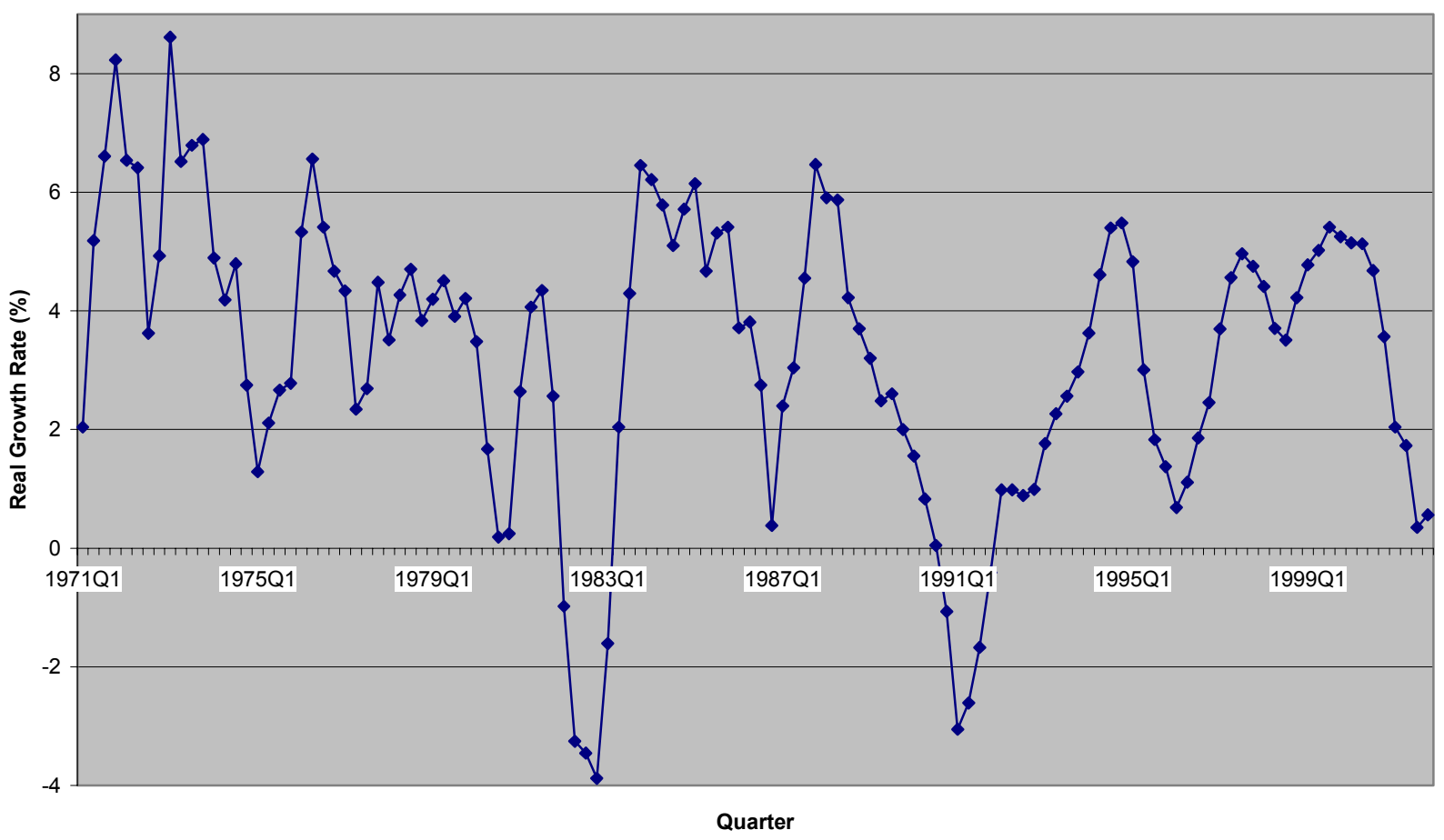


Chart 5: Quarterly Canadian Unemployment Rate (Age 15+); 1976Q1 - 2001Q4; Source:

CANSIM D980745

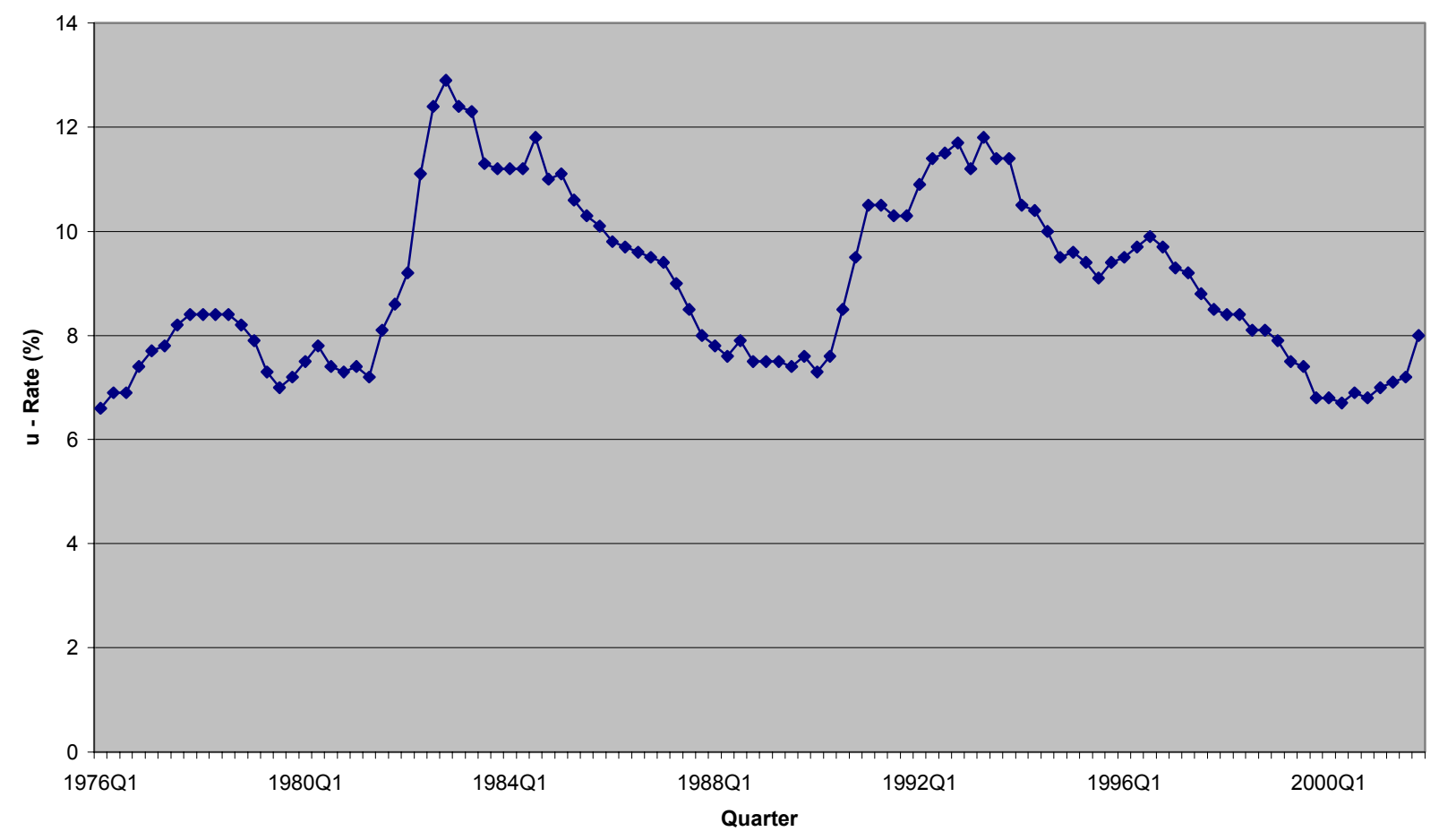


Chart 6: Federal, Provincial and Local Canadian NetDebt/GDP Ratios; Source: CANSIM Series on Net Debt and Nominal GDP

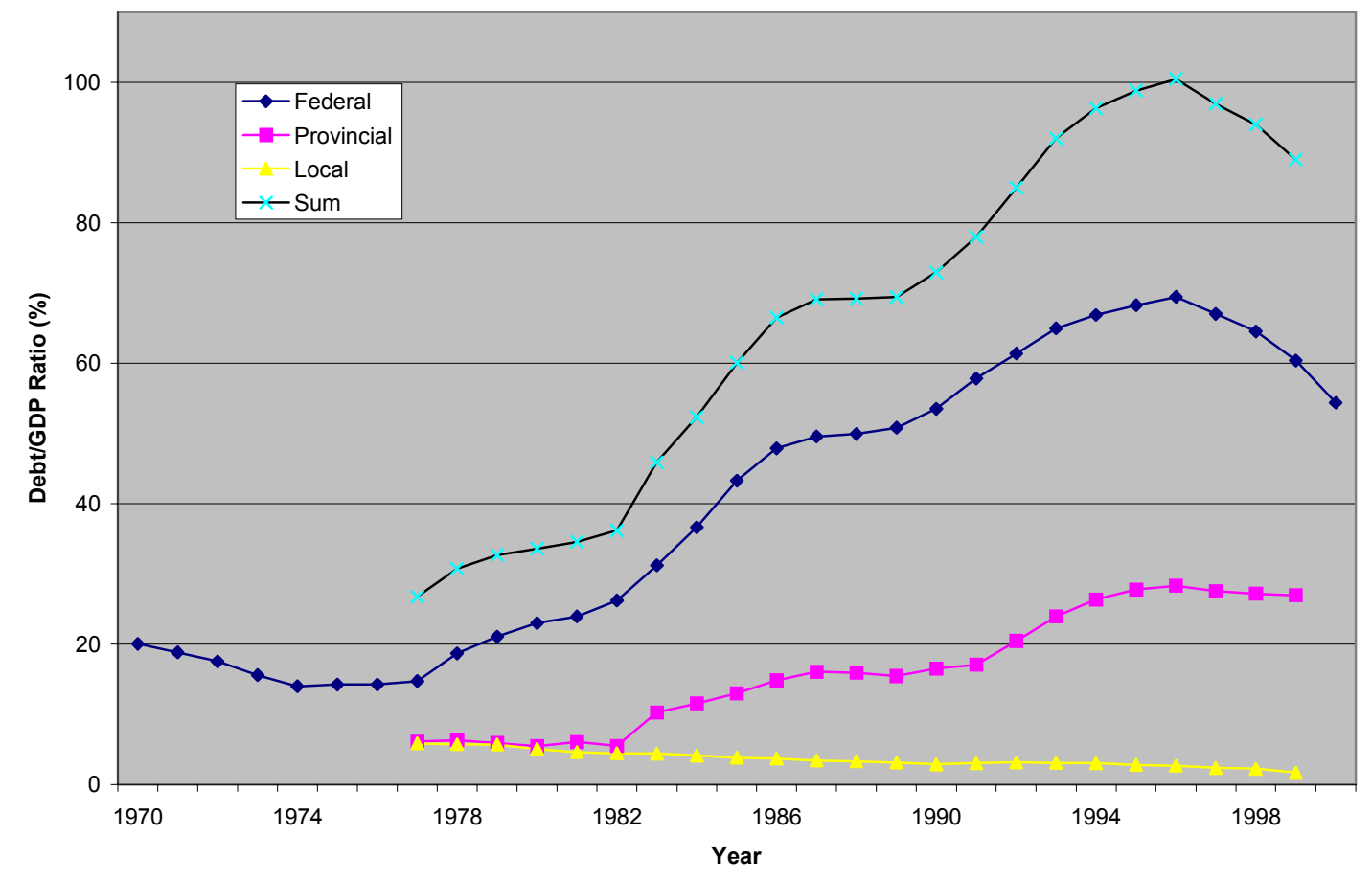


Chart 7: Canadian Net Foreign Debt - GDP Ratio; 1970 - 2000, Annual Data; Source: CANSIM D65219 and D15689

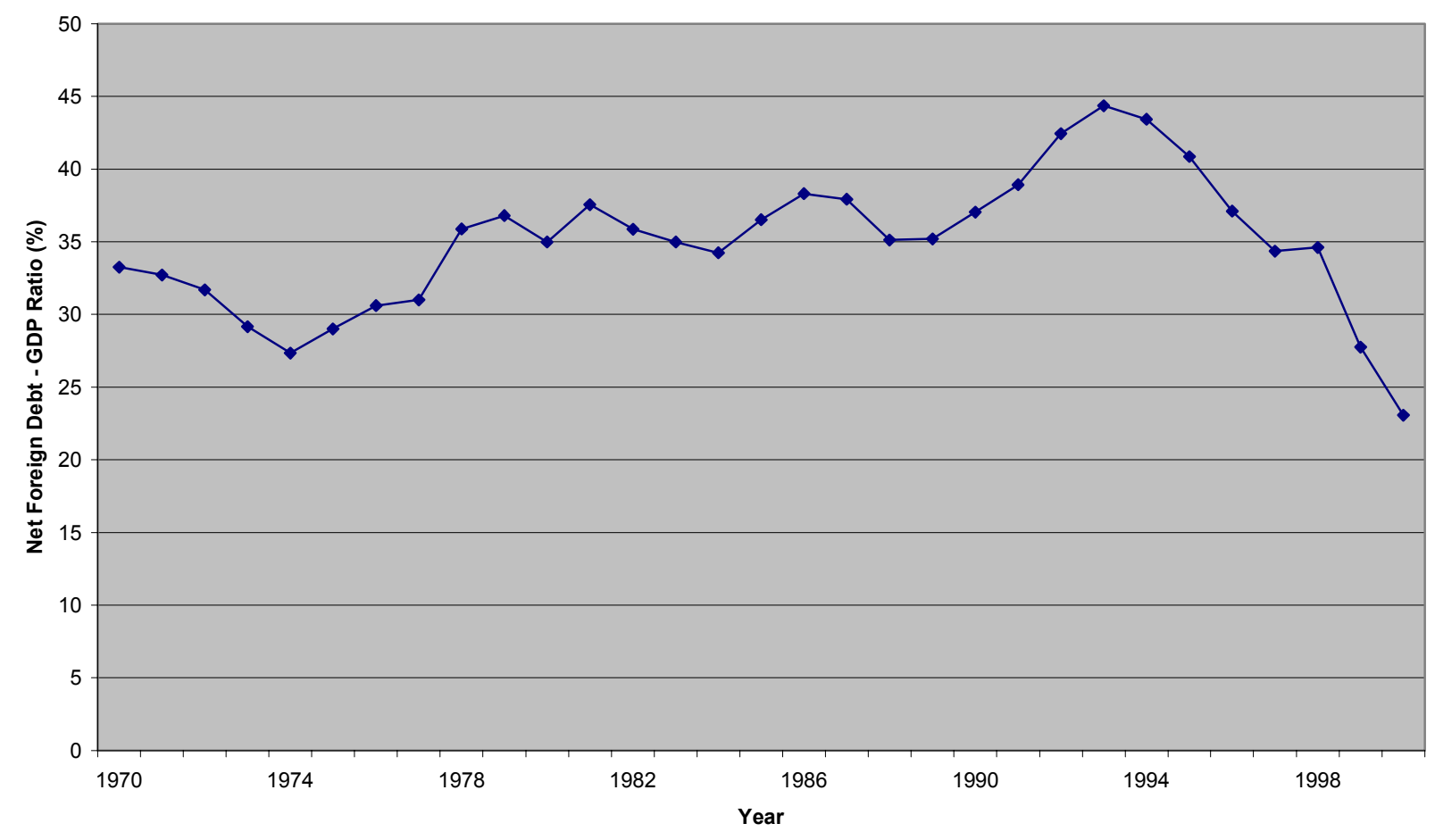


To be sure, no-one would want to attribute all of these results to the monetary order alone. The US-Canada Free Trade Agreement, and its successor the NAFTA, played their part here, as did reforms of the Employment Insurance System. But a monetary order based on inflation targets and supported by budget surpluses has surely had much to do with setting and keeping in motion a virtuous economic policy circle in which monetary stability's influence on interest rates has made fiscal stability easier to attain, which in turn has simplified the monetary authorities' task. The joint effect of these developments has been a benign macroeconomic policy background against which the ongoing microeconomic adjustments made necessary by the NAFTA have become easier to make.

If ever there was a place and time when the "it ain't broken" case could be made for "not fixing" a monetary order, it has surely been Canada in the last four or five years, and yet over this period, there has been a growing opinion among the business community, and among some academic economists too, that the time has come, or at least is fast approaching, to replace the current arrangement with a monetary order based in some way on the United States dollar. Two main arguments are advanced in favour of such a move. The first involves simplistic "me-too" reactions to the launch of the Euro as a virtual currency in 1999, and to the introduction of Euro notes and coins in 2002. The second, more important by far, claims that the Canadian dollar's significant depreciation against the U.S. dollar in the 1990s, and even since 1970s, is symptomatic of some deeper economic malaise that can be cured by abandoning exchange rate flexibility in favour of some sort of fixed rate.

More recently, this second argument has merged into a third, involving an altogether broader agenda for North American Economic integration. Though the events of September $11^{\text {th }}, 2001$, have given a new urgency to this newer argument, and changed its context too, the general question of further North American economic integration had already been placed firmly on the agenda before then, not least by the Bush administration's new ambassador to Canada, Mr. Paul Cellucci, in an interview published by the National Post, a daily newspaper, on June 30, 2001. (Fife and Toulin, 2001) ${ }^{12}$

\section{The Canadian Dollar's Depreciation and The "Lazy Manufacturer"}

Chart 8 tells the story of the Canadian dollar's exchange rate against the U.S. dollar over the last three decades. There has been a depreciation of a little over one third. In the 1970s and early ' 80 s, this could be attributed to a significant degree to Canada's inflation rate being higher than that in the U.S., but for ten years now, this factor has, or ought to have been, working in the opposite direction. One important and under-stressed fact stands out in Chart 8, however: namely, that how big the depreciation of recent years might seem depends crucially upon the starting point one chooses as a basis for comparisons. Since 1990, it has been dramatic, but the exchange rate had already sunk a little below 70 cents for a short time in the ' $80 \mathrm{~s}$. Or, to put it another way, how serious a problem might be posed by the exchange rate's current value depends on whether its trough in the mid 1980s, its peak in the early ' 90 s, or perhaps both, are regarded as anomalous.

\footnotetext{
${ }^{12}$ It should be noted, however, that though Mr. Cellucci broached the issues of labour and goods market integration that might involve a harmonisation of external tariffs and immigration and refugee policies, as well as a common energy policy (which already seems to exist under the NAFTA), he did not explicitly mention the issue of monetary integration.
} 
Some critics of the current monetary order have suggested that the Canadian dollar's depreciation since the early 1970s of a little over 30 per cent. can, in and of itself, be taken as measuring the extent of the fall in local living standards relative to those prevailing in the United States that exchange rate flexibility has either created or permitted. Thus Courchene and Harris (1999b) remarked that the Canadian currency's decline from US\$1.04 in 1974 to US\$0.63 in the late summer of 1968 "represent[ed] an enormous fall in Canadian living standards vis-a-vis the Americans" while Cooper (2001), an exponent of the view that the dollarization of Canada is inevitable, has referred to the currency's decline as "a national pay cut". This is, of course, a debating point, and a misleading one at that, but those who have resorted to it have also made other more substantial arguments about the influence of the exchange rate on living standards which require respectful attention. 
Chart 8: Canadian - U.S. Quarterly Exchange Rate; 1970Q1 - 2001Q4; Source CANSIM B3400

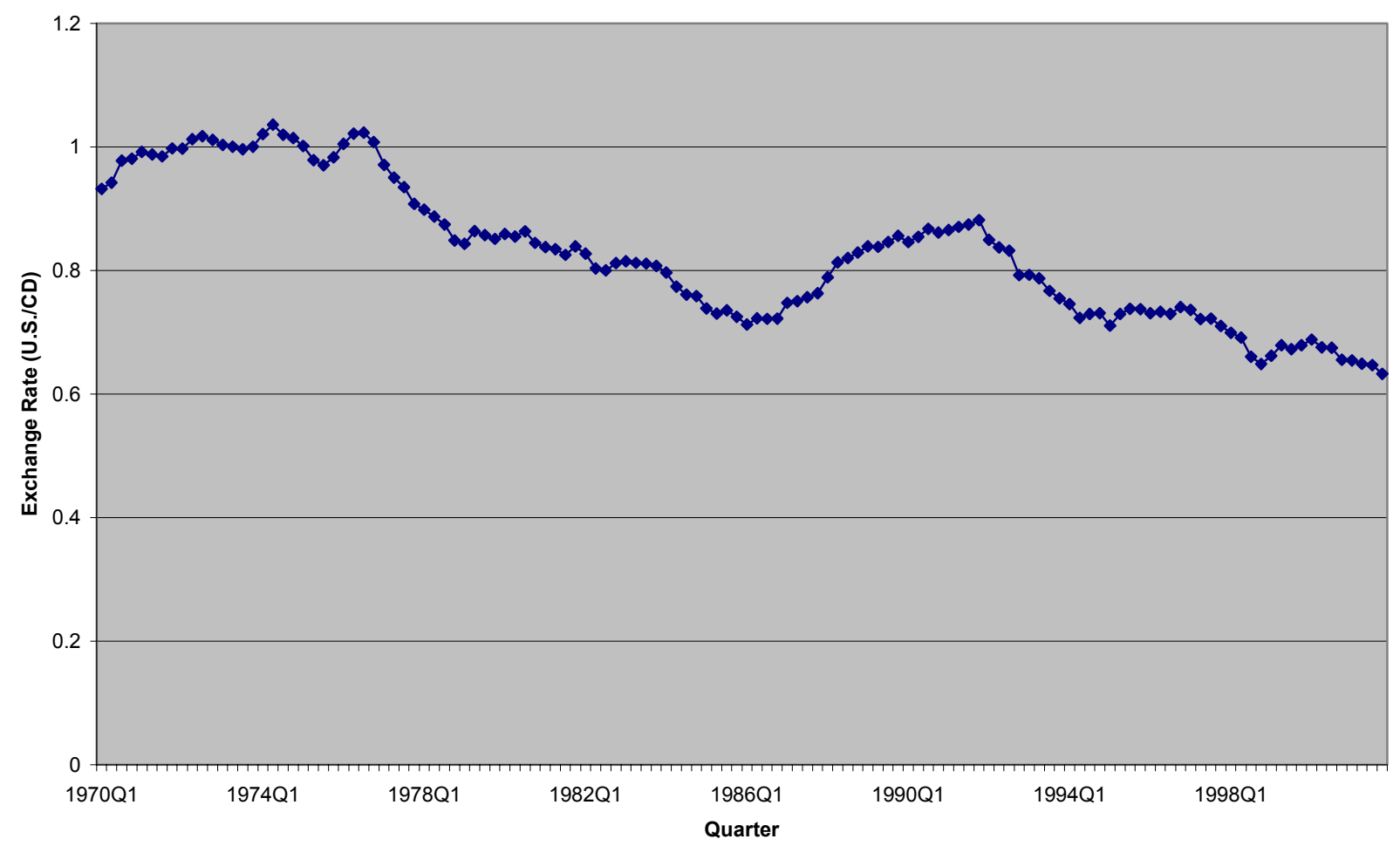

In particular, these critics stress the much discussed matter of labour productivity growth in the Canadian economy, and note that though this improved in the 1990s, particularly in manufacturing, the gain fell short of that attained in the United States. ${ }^{13}$ They then point out that the exchange rate moved from a value significantly above its purchasing power parity level of around 80 cents in 1990, to one significantly below it by the end of the decade, and argue that this decline has itself been an important cause of slow productivity growth in Canada. Two potentially complementary mechanisms are said underlie this causative relationship. The first of these has been termed the lazy manufacturer hypothesis, and suggests that the declining exchange rate has discouraged many firms, particularly exporters, from taking productivity enhancing measures of all sorts. ${ }^{14}$

This idea, though widely believed, is hard to take seriously when it is subjected to analytic scrutiny, and even some critics of the current monetary order who have advanced it, notably Courchene and Harris (1999a) have been careful to term it a "conjecture". It has it that Canadian firms, particularly in manufacturing, when faced with increasing foreign competition from jurisdictions where productivity has been growing rapidly have relied on a declining exchange rate to protect them, rather than take productivity-enhancing measures of their own to meet that competition, as they would have been forced to do under a monetary order involving some sort of fixed exchange

\footnotetext{
${ }^{13} \mathrm{~A}$ more general concern with the behaviour of the standard of living, as measured by GDP per capita, underlies the stress placed on labour productivity in Canadian debates. It is worth noting that business sector multi-factor productivity actually grew a little faster in Canada than in the US in the 1990s. See Pilat (2001). This section of the current paper draws heavily on Laidler and Aba (2002)

${ }^{14}$ These arguments have been advanced by Grubel (1999) and Courchene and Harris (1999a) in particular. The phrase lazy manufacturer seems to have been introduced by John McCallum (1998), who, however, is skeptical of the argument.
} 
rate.

At first sight, this argument seems similar to that which has high inflation created by monetary laxity undermining productivity growth, and perhaps it derives some superficial plausibility from this appearance. However, the arguments are in fact quite different In the case of high and variable inflation, it is uncertainty about the structure of relative prices that is said to deter investment and distort its structure too, hence undermining real economic performance. But, according to the lazy manufacturer hypothesis as applied to Canada in the 1990s, the baleful effects of a declining exchange rate have appeared against a background of low and stable inflation, by way of a mechanism that relies not on uncertainty about a volatile exchange rate, but on the very predictability of exchange depreciation.

From the standpoint of orthodox economic analysis, the main difficulty with the lazy manufacturer hypothesis is its incompatibility with profit-maximisation. If productivity enhancing steps had in fact been readily available to Canadian manufacturers in the 1990s, then the declining exchange rate which permitted their survival without taking such measures must also have provided significant profit opportunities that they failed to exploit. ${ }^{15}$ Only if these firms are satisficers of some sort is this point not sufficient to refute the lazy manufacturer hypothesis. Though there are badly run firms everywhere, some of which may well behave "as if" satisficers, there seems to be no independent evidence that such behaviour is more prevalent in Canada than anywhere else.

Even more compelling here, however, is a growing body of empirical evidence on the details of labour productivity growth in the US and Canadian economies. If the behaviour of some economy wide variable such as the exchange rate lay at the root of poor productivity performance in any economy, one would expect its influence to be by and large across the board, albeit perhaps a little concentrated in sectors directly involved in foreign trade. It is, however, well known by now that the spectacular productivity gains that have been made in the United States in the 1990s have been very narrowly concentrated in the electrical and machinery manufacturing sectors. Outside of these two sectors, the gains have been much more modest. Indeed they have sometimes fallen short of those made in the comparable sectors of the Canadian economy. The upshot is that Canada's lagging labour productivity overall is more than accounted for by two facts: electrical and machinery manufacturing are a much smaller part of the Canadian economy than of the US, and Canadian firms in these sectors have performed relatively less well than their US counterparts. ${ }^{16}$ Furthermore, if one looks for Canadian firms that have performed badly in a absolute sense in the 1990s, these are heavily concentrated among small manufacturers of all sorts, only about ten per cent of which are engaged in exporting. These details of the data might give cause for concern, but it is hard to deploy them in support of the view that the nature of the Canadian monetary order in general, or its exchange rate component in particular, are responsible for the economy's labour productivity performance.

\footnotetext{
${ }^{15}$ The same point may be put in another way. Advocacy of low taxes and of exchange rate fixity often go together in Canadian policy debates, but if the prospect of realising lower output prices from foreign markets would have encouraged higher productivity growth in the 1990s, then it would have been higher, not lower domestic taxes that would have worked in the same direction.

${ }^{16}$ See Rao and Tang (2001), especially Table 2, for evidence on these matters.
} 


\section{The Exchange Rate and the Price of Capital Goods}

Rapid productivity growth in the electrical machinery and manufacturing sectors in the United States in large measure reflects the rapid technical progress that has been made in information and communications equipment, and this equipment is, of course, an input into the production of other goods. Firms that have invested heavily in it in the 1990s should themselves have experienced extra productivity growth as a result. ${ }^{17}$ This point, and the fact that Canada is an important importer of such equipment from the US, requires, as Richard Harris (2002) has forcefully argued, that a second argument linking the exchange rate's depreciation in the 1990s to the economy's productivity performance be taken seriously, namely that rising prices of imported capital goods have discouraged investment, particularly in new technology.

Note, however, that even if this argument is factually correct, which Lamarre (2002) has recently questioned, it is, as both he and Lafrance and Schembri (1999-2000) have stressed, an argument about the effects of a falling real exchange rate on relative input prices. In order to show that such effects as exist can be traced to the workings of Canada's current monetary order, it must be established that the decline in the real exchange rate that undoubtedly took place in the 1990s can plausibly be attributed to the functioning of a flexible nominal exchange rate within that order. If instead, the real exchange rate's behaviour has itself been the consequence of real factors, then under a fixed nominal exchange rate the same real depreciation would have had to take place through other channels. And in that case, the relative price of imported capital goods faced by Canadian firms would still have risen, and would still have tended to discourage productivity enhancing investment.

It is one of the curiosities of the literature on exchange rate regimes that purchasing power parity commands so much attention and respect, not just as a concept to be deployed when making international comparisons of living standards where it is indispensable, but as a theory of the long run behaviour of nominal exchange rates too. The frequency with which the word "misalignment" is used synonymously with "deviation from purchasing power parity" when the exchange rate is discussed in Canadian debates attests to the idea's influence. And yet to use words in this way, and thus rely on purchasing power parity as a guide to the long run equilibrium level of the nominal exchange rate, is equivalent to advancing the hypothesis that, in the long run, the equilibrium Canada - US real exchange rate is a constant. The US, however, is an importer of primary commodities, and Canada is a major exporter. They accounted for just over 30 per cent of Canadian exports at the end of the 1990s, down from about 50 per cent thirty years earlier, though their share in Canadian GDP has remained essentially stable at a little over 10 per cent over that period. Given that world commodity prices are extremely variable, real exchange rate constancy between Canada and the US is highly unlikely, and indeed, what is locally referred to as the "Bank of Canada Equation" is consistent with the proposition that this is not the case. ${ }^{18}$

\footnotetext{
${ }^{17}$ Note that potentially important measurement issues arise at this point. To the extent that productivity growth in equipment producing industries is overstated by the widespread use of hedonic price indices to deflate nominal output, it will be understated in equipment using industries, and vice versa.

${ }^{18}$ In his influential survey of these issues, Kenneth Rogoff (1996) did not mention terms of trade changes as a reason why exchange rates among advanced countries might deviate from purchasing power parity, even though they lie at the centre of many discussions of the behaviour of the exchange rates of less developed commodity producing countries. In more recent work, however, (Chen and Rogoff 2002), he has investigated commodity price effects on the exchange rates of Australia,
} 
The equation in question was first developed in the early 1990s (see Amano and van Norden 1993, 1995) and, unusually in the exchange rate literature, it is still performing well despite its extreme simplicity (see Laidler and Aba 2002 for a recent up-date). This equation makes the real exchange rate a lagged function of three variables: the real price of non-energy commodities, the real price of energy commodities, and the short-term US Canada interest differential. The property that makes this equation "work" is its division of commodity prices into two components. Non-energy prices enter, and strongly, with the expected positive sign, but energy prices usually take a perverse sign, and sometimes, particularly when more recent data are used, are statistically insignificant too. ${ }^{19}$

The Bank of Canada equation has proved to be rather robust, particularly as far as the role of non-energy commodity prices is concerned, even in the face of data generated since it was first developed. Chart 9 displays the outcome of the following standard exercise reported by Laidler and Aba (2002). The equation in question was estimated over the period 1970-1995, with the coefficient on commodity prices being allowed to take a different value in each decade, to pick up the effects of what is believed to be the declining importance of commodities among Canada's exports, and then used as the basis of a dynamic simulation to generate forecasts of the nominal exchange rate down to the end of last year. This chart shows in particular that the equation picks up the exchange rate's decline in the mid-1980s, and attributes its subsequent recovery to a combination of tight domestic monetary policy in Canada, and a world-wide commodity price boom. It also suggests that the decline in the exchange rate in the latter half of the 1990s, which helped to start the current debate about Canada's monetary order, was the predictable consequence of the behaviour of commodity prices and interest rates over that period.

More generally, but crucially as far as the debate about the sources of poor productivity performance are concerned, there is no evidence that the decline in the real exchange rate during the 1990s, which undoubtedly has made imported capital goods more expensive and may therefore have contributed to the relatively slow growth of labour productivity in Canada over that period, can be attributed to the monetary order. ${ }^{20}$ Rather it seems to have been the consequence of deeper seated real forces that have made a large fraction of Canadian exports less valuable than they previously were. If this is so, then under any monetary order based on a fixed nominal exchange rate, the burden of adjustment would have fallen on domestic prices and money wages. Indeed, Robson and Laidler (2002)

Canada and New Zealand. They are present in all three cases, but seem more fragile for Canada than for the other two countries.

${ }^{19}$ Why energy prices enter the equation in this way is a matter of ongoing debate. One explanation, favoured by Bank of Canada researchers, is that Canadian manufacturing exports are particularly energy intensive, and that the depressing effect of rising energy prices on their international competitiveness more than offsets the direct effect on the real exchange rate of the prices of energy exports themselves. Another, due to John Helliwell (2000), suggests that the result is an econometric artifact stemming from the fact that large swings in energy prices are often associated with international political developments that trigger a flight to quality effect on the US dollar's international value. Hence rising energy prices have been correlated with US dollar appreciations because both have had a common cause, and not because one has brought the other about.

${ }^{20}$ The reader is nevertheless reminded of Lamarre's (2002) skepticism on this question. He argues that the decline in Canadian investment relative to the US in the 1990s is as easily interpreted as a return to matters as they were for most of the 1980 s, as a response to the fall in the real exchange rate. 
Chart 9: Dynamic and Static Simulations for the Canadian Dollar, Decade-by-Decade, 1973Q22001Q4

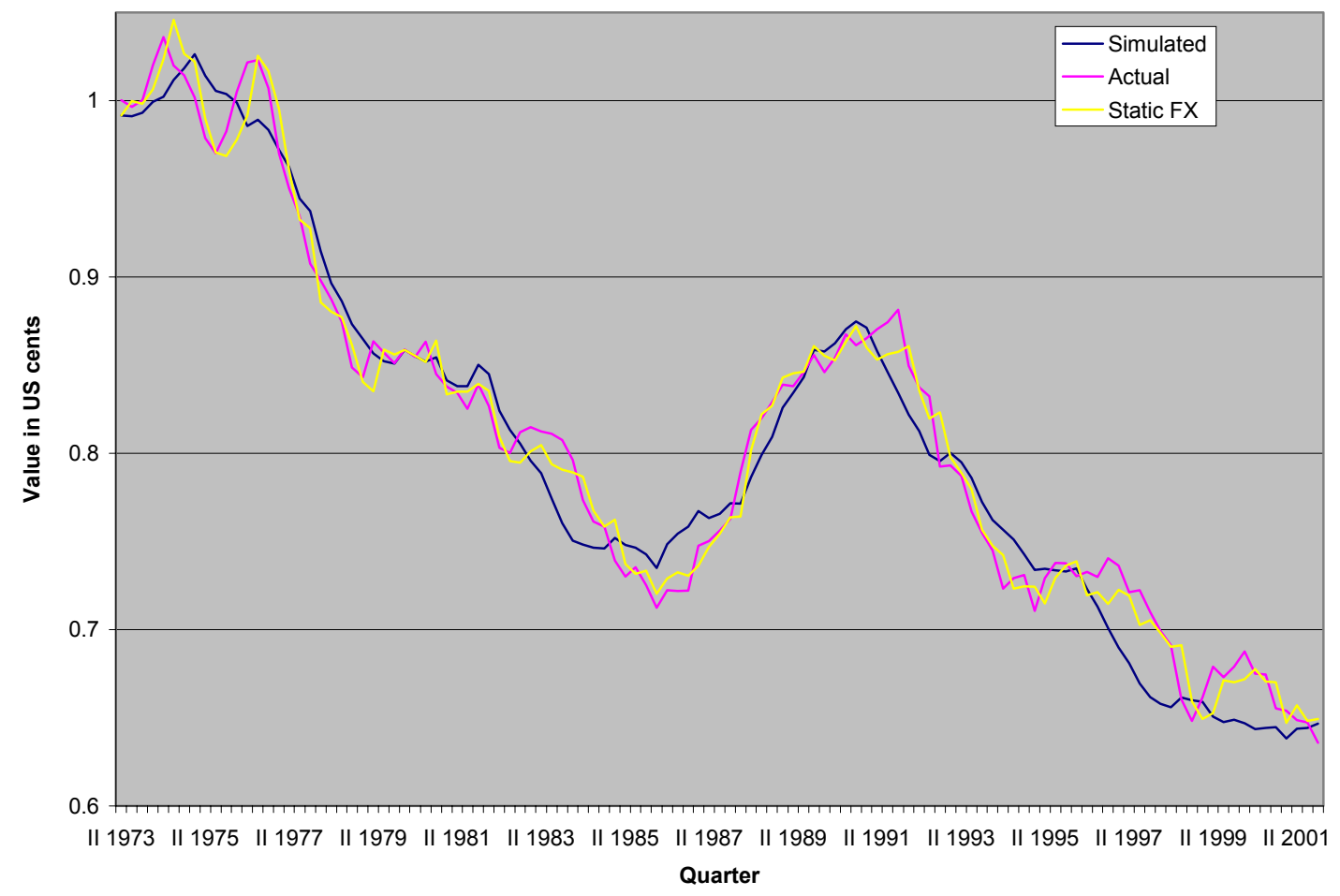

estimate that, had a fixed nominal exchange rate been in place, an average rate of deflation (as measured by the GDP delflator) of between 1 and 2 per cent per annum would have been required in the second half of the 1990s to bring about the fall in Canada's real exchange rate required by declining commodity prices. 
There is, then, a strong burden of proof upon those who argue that some sort of fixed exchange rate would have served Canada well in recent years to explain either why they believe that such a deflation would have been unnecessary, or how it could have been accomplished without a recession that would have tended to reduce, not increase, the rate of productivity enhancing investment relative to that which has actually been achieved. ${ }^{21}$

\section{Proposals for a Common North American Currency}

Even though there is no evidence that Canada's post-1991 monetary order has contributed to a poor real economic performance on any front, proposals for replacing it began to attract attention in 1998. No serious commentator has advocated the simple adoption of an adjustably pegged exchange rate of the traditional type as an end in itself, though Harris (2001) suggested that an exchange rate regime resembling the 1990s European Exchange Rate Mechanism might be a useful first step towards fuller North American monetary integration, while Courchene and Harris (1999a) argued that a fixed rate regime, whose details they did not spell out, could play the same role prior to the establishment of a fully fledged North American Monetary Union (NAMU) based on a new common currency. However, other opponents of the current order, notably Herbert Grubel (1999), have agreed from the outset with its defenders that the problems of establishing credibility for a pegged exchange rate, whose value could be set, and therefore changed, by a simple administrative decision taken by the Minister of Finance, would make such a half-way house inferior to either extreme.

A legislatively fixed value for the exchange rate is the next step along the continuum that lies between a pegged rate and a common currency. The recent collapse of Argentina's version of such an arrangement (usually, though misleadingly referred to as a currency board) has been widely noted in Canada, however. ${ }^{22}$ That is why a common North American currency is increasingly seen as the alternative of choice to current arrangements. Indeed just such an arrangement was proposed by Grubel in the (1999) pamphlet that set the current Canadian debate in motion.

Grubel, however, working from the European blueprint, envisaged a new North American currency - the Amero - with monetary policy overseen by a new supra-national central bank. This proposal suffers from the fatal defect, more obvious with hindsight than initially, that neither the United States authorities nor the United States electorate has shown the slightest interest in it. In the late 1990s, when Grubel prepared his proposal, he was able to argue that, in the then immediate future, currency competition from the soon-to-be-launched Euro might sufficiently threaten the international role of the dollar that the creation of a new North American currency could become attractive, both economically and politically, to the US. At the current juncture, and whatever might happen in the longer term, this possibility does not seem to be on any near- or even medium-term horizon. Thus, it

${ }^{21}$ Buiter (1999), taking an outsider's view of the North American debate, seems to me to underplay the importance of this economic argument.

${ }^{22}$ Argentina should be used with care as an example in the Canadian debate. An important factor in making its problems particularly acute was the that its exchange rate was fixed to the US dollar, a currency that was important for its foreign borrowing, but relatively unimportant for its trade, which is mainly with other Latin American countries and Europe. These features have no parallel in the case of Canada, for which the United States is, essentially, the "rest of the world" for both the capital and trade accounts. 
is now understood that, if Canada is to adopt a monetary order based on a common North American currency, that currency is going to be the United States dollar, and it is this form of monetary integration that I shall henceforth discuss.

Some commentators, for example Cooper (2001), have suggested that market forces alone will lead to the voluntary adoption of the US dollar as Canada's domestic currency. However, such hard evidence as exists on these matters suggests that any tendencies in this direction are hard to discern. Robson and Laidler (2002) show that Canadian residents' holdings of US dollar denominated accounts in domestic banks rose in the 1990s to about 9 per cent. of M3, but also that this rise simply restored them to levels that had already been seen in the 1970s. As for the use of the US dollar as a unit of account for transactions between agents resident in Canada, preliminary work by the Bank of Canada (Murray and Powell 2002) suggests that, though not unknown, the practice is relatively rare. And this is to say nothing of the well established result that the network externalities inherent in monetary exchange present a barrier to the market driven replacement of one currency by another that is sufficiently strong to resist all pressures except those associated with extremely high and variable domestic inflation, a phenomenon that is completely absent from Canada.

\section{The Economics of Adopting the US Dollar}

If Canada is to adopt the US dollar, then, that will have to be the outcome of a deliberate policy choice, and the strongest argument in favour of such a choice is the reduction in transactions costs that such a move would bring about. Foreign exchange conversion costs in cross border trade would vanish, as would those associated with hedging against exchange rate risks. With only two currencies involved, or three if Mexico makes a similar choice, the gains here would be smaller than those realised in Europe where eleven currencies were replaced by the Euro, but they would not be negligible. Robson and Laidler suggest that, for Canada, transactions cost savings alone might amount to as much as 0.26 per cent. of GDP. Such cost reductions would presumably lead to an increase in trade, and hence to further gains to economic welfare.

One study (Frankel and Rose 2000), widely cited in the Canadian media, has suggested that a gain of as much as 37 per cent in Canadian GDP might be created over a decade by the adoption of a common North American currency. Now Frankel and Rose's results are contentious. They are based on data for groupings of economies, many of which, (eg. the East Caribbean currency union, The Channel Islands, the Isle of Man and the UK) bear scant resemblance to a potential North American currency zone, and are affected by data generated before and after the break-up of currency unions between European powers and African colonies when far more than monetary arrangements changed. Furthermore, they have been shown to be econometrically fragile by Pakko and Wall (2001), while Thom and Walsh's recent (2002) time series study of the Irish economy finds essentially no effect on its real performance from the end of its common currency arrangement with the UK, and also notes that the beginning of later and still continuing "Irish miracle" predated the establishment of the Euro.

Even if we ignore all this, which we probably should not, it is as well to note that Frankel and Rose's estimate of the likely gains to Canada from adopting a common North American currency has two components to it: first the influence of a common currency on the volume of trade, and second the influence of increased trade on 
GDP. Relevant to the first effect are recent estimates by John Helliwell (1998) that, relative to the forecasts of a standard "gravity model", the "border effect" on Canadian - US trade is to reduce its volume about fourteen-fold, so Frankel and Rose's suggestion that the adoption of a common currency might increase trans-border trade about four-fold does not seem to be a priori unreasonable. After all, the relatively small tariff reductions brought about by the FTA and NAFTA seem to have reduced the "border effect" to Helliwell's estimate of fourteen from John McCallum's (1995) original estimate of over twenty. However, the second step in the Frankel-Rose conclusions about the income generating potential of a common currency, namely their claims about the influence of trade creation on real output, gives more grounds for skepticism.

Recent work by Elton Fairfield (2001) throws light on this issue in a specifically North American context. Fairfield points to the well known fact, long ago noted by Robert Mundell (1961) in his pioneering paper on optimal currency areas, that the goods produced on the two sides of the US.-Canadian border at any particular longitude are rather close substitutes for each other. Thus the pattern of comparative advantage in North America implies that the major gains are to be made, not from north-south, but from east-west trade. That being the case, the existence of quite small artificially imposed barriers to north-south trade can have a large negative effect on its volume, and their removal can lead to large increases. This hypothesis, for which Fairfield presents empirical support based on calibration exercises, both explains why border effects in North America are large, and why relatively small changes in cross-border transactions costs, such as the NAFTA brought about, can also have a large effect on their magnitude; and it also suggests that the transactions cost reductions associated with the adoption of a common currency could have similarly large effects on trade volumes.

However, this hypothesis has an important corollary which Fairfield does not explore: namely, that the output, not to mention the welfare, losses and gains implicit in border effects and changes in transactions costs are small in the US.- Canada case. If this is so, then Frankel and Rose's own skepticism about their estimates of the gains to Canadian output that might be realised by adopting the US dollar, estimates which are, after all, extrapolated from results obtained using data from other times and places, is well justified. All in all, it is hard to resist the Helliwell's suggestion that the best thing to do about this whole contentious question is await the outcome of the natural experiment now taking place in Europe, where a common currency has been adopted by the Euro 12 countries as a major element in a concerted drive to create a single market in goods services and capital, but not by three others also involved in that drive, namely Denmark, Sweden and the UK.

Any gains from lower transactions costs associated with monetary integration would in any event come with a price in the Canadian case. To begin with, if Canada's real exchange rate fluctuations are driven by market fundamentals that monetary integration would not change, then under a common currency arrangement of any sort, Canada would not simply import US price level behaviour, as is widely believed. This would only be the outcome were the US.- Canada real exchange rate to remain constant over time, but, as we have seen, this has clearly not been the case in the past. The current monetary order enables Canada to maintain stable inflation while absorbing real exchange rate changes by movements in the nominal exchange rate, and this ability would be lost under a common currency. Given that Federal Reserve policy continues in future as it has in the recent past, to deliver low and stable domestic inflation for the US, then either domestic inflation in Canada would become more 
variable than it now, or Canadian output and employment would fluctuate more, or both.

How serious a problem this would pose depends on whether monetary integration is envisaged as a measure in its own right, or as part of a broader package that also involves goods, and particularly labour, market integration. At present, fluctuations in the demand for labour, particularly in commodity production, that are associated with swings in world commodity prices, are usefully buffered to some extent by nominal exchange rate changes. With the latter mechanism eliminated under a common currency, all of the pressures involved here would be brought to bear on domestic money wages and prices, and given Canada's rather (by North American standards) rigid labour market, this would involve potentially serious fluctuations in employment. Absent a common North American labour market, these would have to be accommodated within Canada, but they would present much less of a problem were it possible for workers displaced from the Canadian commodity sector to seek work anywhere in North America. Linguistic and cultural barriers to international labour mobility would almost certainly prove to be much smaller there than they are in the Euro zone. Even so, future European experience in responding to asymmetric shocks under a common currency will provide useful evidence on the relevance of this matter to the North American case.

These points are well understood in Canada, but much less attention has been paid to another set of important issues to which Robson (2001) and Robson and Laidler (2002) have recently drawn attention. They point out that there can be a good deal more to monetary integration than the adoption of a common currency, depending on the form it takes. Simple unilateral dollarization of the Canadian economy along Panamanian or Ecuadoran lines would leave Canadian regulatory and clearing systems as they currently are. To the extent that the harmonization of such arrangements with their US. counterparts would be required to achieve full integration of the North American monetary system, then gains from unilateral dollarization might turn out to be disappointingly low. Indeed there might be losses, because unilateral dollarization would deprive the Canadian monetary authorities of the ability to create new liquidity at will for the financial system should circumstances require it.

The importance of this last factor was brought home dramatically by the events of September 11, when the Canadian clearing system was saved from breakdown only by an immediate and large injection of high powered money by the Bank of Canada. Furthermore, it should be noted that the final breakdown of the Argentinian monetary system was precipitated by a banking crisis which might have been prevented had that country's central bank been able to provide unlimited lender-of-last-resort facilities when the system first began to encounter liquidity problems. To be sure, under unilateral dollarization, the Bank of Canada, or indeed the large chartered banks, could hold stocks of US dollars, or arrange US dollar lines of credit, so the Canadian system would not be entirely devoid of access to liquidity in times of crisis, but these expedients would be costly, and could never provide quite the degree of security to the Canadian financial system that is currently available from a central bank that can create domestic money in unlimited amounts.

These considerations strongly suggest that unilateral dollarization would raise costs of doing business for Canadian-based financial institutions, and expose them to greater risks too, thus increasing the costs of anyone utilising their services. It is not hard to imagine that, in such circumstances, many of these institutions would migrate to the United States to avail themselves of the central banking services available from the Federal Reserve 
System, leaving domestic customers to be serviced by Canadian branches or subsidiaries. Such adverse effects on Canada's financial services sector are presumably not among the results that advocates of North American monetary integration have envisaged.

The technical solution to these problems is simple enough. Instead of undertaking unilateral dollarization, Canada might instead try to negotiate a fuller integration of its monetary system with that of the United States. It is sometimes suggested, for example, that full monetary integration might be achieved by having the Canadian chartered banks become members of the Federal Reserve system, a step which would ensure them access to the central banking and lender of last resort services provided by the Fed, as well as (perhaps along with other relevant financial institutions) access to US clearing systems. In addition to giving Canadian institutions access to the same lender-of-last-resort facilities as their American counterparts, such negotiated monetary integration would also bring them under the same regulatory framework, and hence enable them to compete on an equal footing in the North American market. The economic drawbacks associated with unilateral dollarization would thus be overcome. It is usually taken for granted by those who advocate such a move that it would also involve reconstituting the Bank of Canada as a new district bank of the Federal Reserve system, a measure that would also have the advantage of providing a Canadian voice at the table where monetary policy would be made for North America.

\section{The Politics of Adopting the US Dollar}

But, and it is a very large but indeed, this solution, so simple from an economic point of view, raises extraordinarily difficult political issues. As was noted earlier, the Bank of Canada is a crown corporation, but district banks of the Federal Reserve system are privately owned by those commercial banks operating in their districts which are also members of the System. Furthermore, unlike the Bank of Canada as currently constituted, Federal Reserve district banks have supervisory and regulatory authority over the member banks that own them, including the power to approve mergers among them, an authority which, in Canada resides with the Competition Bureau and Minister of Finance. To be sure, shares in district banks are not marketable, while the powers of their holders to influence district bank decisions, let alone, system decisions, are severely limited, and these arrangements work well enough in the United States, where there are literally thousands of small banks. But the Canadian banking system is dominated by six large institutions, and the rules which work well in limiting member banks' powers in the US might not be up to the job in Canada.

In any event, is hard to imagine the Canadian electorate supporting the sale of the Bank of Canada to the chartered banks, which would then be regulated by it, and it is equally hard to imagine the US electorate, with its long-standing suspicions of concentration in banking, welcoming the addition of a large district dominated by six banks into their own Federal Reserve system. But if the unilateral adoption of the US dollar would have unattractive economic consequences for Canada, and if the measures needed to ensure the complete integration of the Canadian system into the Federal Reserve system are unlikely to attract political support in either Canada or the United States, then advocates of Canada's adopting the US dollar need to do some hard thinking about just what form of North American monetary integration would both meet Canada's economic needs, and attract political support both in Canada, but crucially in the United States too. 
Any form of monetary integration that could conceivably meet Canada's economic needs would have to provide Canadian banks with access to central banking services of the same quality as are available to their US competitors, and subject them to a regulatory and supervisory regime that did not put them at a competitive disadvantage. To achieve these ends, the active co-operation, not just of the US monetary authorities, but of the US Congress and executive as well would be required, and it is not clear how much of the needed co-operation would be forthcoming. It is worth recalling, for example, that, in 1999, Argentina's attempts to negotiate a form of dollarization were gently but firmly rebuffed by the United States. As Lawrence Summers (1999), at that time under-secretary at the US treasury, remarked:

“. . . it would not, in our judgement, be appropriate for the United States authorities to extend the net of bank supervision, to provide access to the Federal Reserve discount window, or to adjust bank supervisory responsibilities or the procedures or orientation of US monetary policy in the light of another country deciding to adopt the dollar."

Now there is a degree of political support in the United States for dollarization in Latin America, to the extent of a willingness in some quarters to concede seigniorage revenue to dollarizing countries, (See US Senate 1999) and Canada is surely of greater economic and political importance to the United States than Panama, Ecuador, El Salvador or Guatemala, the countries in Latin America that are currently dollarized. However, it should be noted that, in the newspaper interview referred to earlier, and in a number of subsequent statements, Ambassador Cellucci has always been careful to state that, in seeking greater North American economic integration, the United States envisages no movement towards the kind of supra-national political arrangements that have emerged in Europe. Such statements have been read among Canadian supporters of North American economic integration as implying that the United States understands and respects Canada's concerns about its national sovereignty.

This, however, is surely a partial reading of the Ambassador's meaning. His remarks also seem to imply that the United States has no intention of ceding any of its own national sovereignty to any other country or organisation. In the context of proposals for monetary integration, which, surely significantly, the Ambassador has not explicitly discussed, such a stance suggests that, the coming to power of a new Administration notwithstanding, US policy has not changed since Secretary Summers made his statement in 1999. If this is so, then no form of North American monetary integration that would see Canada exerting political or administrative influence over the United States monetary order is politically acceptable there.

It seems likely, then, that any form of North American monetary integration that might interest the United States would involve monetary policy being made in Washington for the whole of North America by a Federal Reserve Board appointed by the President of the United States, and accountable to the American electorate through the Congress. The Canadian electorate would have no mechanisms available to it to hold those policy makers accountable for the effects of their actions on Canada, therefore. As to the supervision and regulation of Canada's financial system under monetary integration, it is hard to believe that the United States authorities would be willing to negotiate the provision of central banking services to a set of institutions that remained subject to a separate and distinct regulatory regime. Note that Secretary Summers explicitly linked these matters in his statement. Either, 
then, Canada would retain a separate system with the disadvantages already described, or these functions too would be exercised according to rules laid down in the US, with no recourse for the Canadian electorate through political channels, should they be adversely affected, or think themselves to be adversely affected by their application.

The transparency of monetary policy, and the political accountability of those who make it (not to mention of supervisors and regulators too) is a feature of Canada's current monetary order upon which much energy has been, and continues to be, expended. It is hard to believe that the electorate would find their surrender acceptable. ${ }^{23}$ It will, therefore, be difficult indeed, perhaps impossible, to find a form of North American monetary integration that would be simultaneously economically efficient in Canada and politically acceptable on both sides of the USCanadian border.

\section{Summary and Policy Implications}

Some of the arguments presented above, and some of the conclusions drawn are surely uncontroversial. The monetary choices that currently face Canada lie not between exchange rate regimes per se but between competing monetary orders, and both of the alternatives currently being considered are viable from the technical economic point of view. Inflation targeting, supported by conservative fiscal policies, has delivered low and credible inflation, and the economy's real performance in the last few years has been excellent by the standards of the preceding three decades. On the other hand, some form of monetary integration with the United States, whether it were to take the form of unilateral dollarization or a negotiated absorption of the Canadian monetary system into that of the US also look feasible from a technical economic standpoint. There are obvious advantages in the way of reduced transactions costs to be had from such a monetary order, furthermore, if it takes the second form.

North American monetary integration might nevertheless have some economic drawbacks. To stress the importance of terms-of-trade changes as influences on Canada's real exchange rate leads directly to the view that a flexible nominal exchange rate is extremely useful in helping to reduce the shocks that these would otherwise impart to domestic money wages and prices. These are strong arguments, well grounded in theory and empirical evidence, but two points nevertheless must be noted. First, it may be that, under monetary integration, Canadian institutions would adapt so that nominal wages and prices would become more flexible; and second, were monetary integration to be accompanied by measures to enhance goods and labour market integration, then the resource reallocations that occur in response to real shocks would have their consequences spread across a much bigger market than at present, and the case for easing them by way of nominal exchange rate adjustments would be weakened. ${ }^{24}$ On the economics of the matter, then, it is possible for reasonable people to disagree about where the balance of advantage actually lies here between the status quo and monetary integration of some sort.

\footnotetext{
${ }^{23}$ Mundell (2001) gives an extensive and extremely interesting historical survey of the various forms that monetary integration among sovereign states may take and has taken. He is careful to note that in some circumstances it may involve one or more countries ceding sovereignty to another, which then becomes a monetary hegemon, but he does not discuss the extent to which such arrangements impinge upon the liberal political principle that policy makers should be accountable to those on whose behalf they operate.

${ }^{24}$ The reader is reminded yet again that evidence on these matters will in due course be provided by the natural experiment currently under way in Europe.
} 
The critical issues at stake are not economic but political, and they are often stated in terms of national sovereignty. Now national sovereignty is eroding on many fronts across the world, and Canadian commentators often point to developments in Europe as an example to be emulated in North America. However, European nations have ceded sovereignty to EU-wide institutions - the Council, Commission, Court, Parliament, and in monetary matters to a Central Bank, - and, though there are complaints about a "democratic deficit" at the European level of government, citizens of all European nations are in the same position vis-a-vis its institutions. Given current American attitudes, however, which from an American standpoint are surely quite reasonable, it is hard to envisage the United States ceding any control in matters of monetary policy or financial regulation and oversight to any officials who are not fully and solely accountable to the domestic electorate.

The only form of North American monetary integration that is politically feasible, therefore, would involve Canada in ceding sovereignty over monetary matters, not to some supra-national institution which would wield its authority on behalf of all members of a North American Monetary Union, and be accountable to members of the Canadian electorate among others, but to authorities answerable only to the elected government of a neighbouring nation. Such a step would involve not just a surrender of Canadian national sovereignty, but much more importantly, a significant attenuation of the authority and accountability of representative government as it would affect Canadian citizens. It is in this latter effect that constitutes the really unpalatable political consequence of North American monetary integration relative to the maintenance of the current monetary order, and it deserves more attention than it is currently getting either in the context of the Canadian policy debate, or, more generally, in the academic literature on monetary unions.

Finally, it is worth recalling that Canada's current monetary order is coherent and is functioning well, and that it is hard to find serious evidence in support of the claims made by its opponents that its workings have had seriously adverse effects on the economy. In the light of these considerations, and in the light of the grave political problems implicit in North American monetary integration, it is hard to make case for Canada's doing anything other than persisting with its monetary status quo.

\section{References}

Amano, R. and van Norden, S. (1993) A forecasting equation for the Canada-US dollar exchange rate, in The Exchange Rate and the Economy, Ottawa, Bank of Canada

(1995) Terms of trade and real exchange rates: the Canadian evidence, Journal of International Money and Finance 14, (April) 83 - 104

Buiter, W. (1999) The EMU and the NAMU: what is the case for North-American monetary union? Canadian Public Policy 25 (Sept.) 285-305

Canada, Parliament, House of Commons Standing Committee on Finance, Sub-committee on the Bank of Canada (The Manley Committee) (1992) The Mandate and Governance of the Bank of Canada Ottawa 
Chen, Y-C. And Rogoff, K. (2002) Commodity currrencies and empirical exchange rate puzzles, IMF Working Paper WP/02/27, Washington DC.: IMF

Courchene, T. J. and Harris, R. G. (1999a) From Fixing to Monetary Union: Options for North American Currency Integration, Toronto, C. D. Howe Institute

(1999b) Canada and a North American monetary union Canadian Business Economics (Dec.) 5-12

Cooper, S. (2001) Time for US loonie National Post November 9

Fairfield, J. E. (2001) Canada-US Border Effects - An Explanation, unpublished doctoral dissertation, Dept. of

Economics, University of Western Ontario, London, Canada

Fife, R. and Toulin, A. (2001) U.S. aims to dismantle borders National Post June 30, A1 \& A6

Fischer, S. (1995) Central bank independence revisited American Economic Review 85 (Papers and Proceedings) 201-206

Frankel, J. and Rose, A (2000) An estimate of the effect of currency unions on trade and growth, NBER Working Paper 7857

Furstenberg, G. von (2000) A case against US dollarization Challenge 43 (July-Aug.) 108-120

Grubel, H. G. (1999) The Case for the Amero: the Economics and Politics of a North American Monetary Union, Vancouver, the Fraser Institute

Harris, R. G. (2000) From fixing to NAMU: redressing Canada's sinking float, paper presented at a Bank of Canada conference on The Case for Flexible Exchange Rates Revisited Ottawa, Bank of Canada (2001) Symbol of Weakness, Financial Post Nov. ${ }^{\text {st }}$, FP15

Helliwell, J. (1998) How Much do National Borders Matter? Washington D. C., The Brookings Institution (2000) Assessing the evidence about the effects of exchange rate systems, contribution to a panel discussion at conference on The Case for Flexible Exchange Rate Revisited, Ottawa, Bank of Canada Heymann, D. and Leijonhufvud, A. (1995) High Inflation London, Oxford University Press

Johnson, D. R. (1990) The zero inflation target: do Wilson and John Crow agree? Canadian Public Policy 14 (Sept)

Jonung, L. (2002) National or international inflation targeting: the Wicksellian dilemma of the Euro-outs (Sweden and the UK) in the EU Paper prepared for the Robert Schuman Centre workshop on Currency Independence in an Interdependent World, Brussels, European Commission, mimeo

Lafrance, R. And Schembri, L. 1. (1999-2000) The exchange rate, productivity and the standard of living Bank of Canada Review (Winter) 17-28

Laidler, D. (1991) How Shall We Govern the Governor? A Critique of the Governance of the Bank of Canada Toronto, C. D. Howe Institute (1999) The exchange rate and Canada's monetary order Working Paper 99-7 Ottawa, Bank of Canada. - and Aba, S. (2002) Low Productivity Growth: The Exchange Rate Connection and Commodities Commentary Toronto, C. D. Howe Institute - and Robson, W. B. P (1993) The Great Canadian Disinflation Toronto, C. D. Howe Institute Lamarre, J-F., (2002) The Effect of the Real Exchange Rate on Canadian Productivity, unpublished M.A. thesis, 
Dept of Economics, McGill University, Montreal, P.Q.

Lipsey, R.G. (ed.) (1990) Zero Inflation: The Goal of Price Stability Toronto, C. D. Howe Institute

McCallum, J. (1995) National borders matter: Canada-US regional trade patterns American Economic Review 85 (June) 615-623

- (1998) Drivers of the Canadian dollar and policy implications Current Analysis, Toronto, Royal Bank of Canada

Mundell, R. (1961) A theory of optimum currency areas American Economic Review 51 (Sept.) 717-725 (2001) Money and the sovereignty of the state in A. Leijonhufvud (ed.) Monetary Theory and Policy Experience Houndmills, Palgrave, in association with the International Economic Association

Murray, J. and Powell, J. (2002) Dollarization in Canada (the buck stops there) Ottawa, Bank of Canada, mimeo.

Orr, D. (1999) The Canadian Dollar: Why Do Such Bad Things Happen in Such a Good Economy, Ottawa, WEFA

Pakko, M. R. and Wall, H. J. (2001) Reconsidering the trade-creating effects of a currency union FRB of St. Louis Review 83 (Sept.- Oct) 37-46

Pilat, D. (2001) Productivity growth in the OECD area: some recent findings International Productivity Monitor \#3 (Fall) 3-18

Rao, S. and Tang, J. (2001) The contribution of ICTs to productivity growth in Canada and the United States in the 1990s, International Productivity Monitor (Fall) 3 - 18

Robson, W. B. P (1990) Not so fine tuning: Bank of canada policy and inflation since 1986 Commentary, Toronto, C. D. Howe Institute, (Aug.)

-------- (2001) New currency regimes: how green the grass? how high the fence? Policy Options 22 (May) 45-50 - and Laidler, D. (2002) No small change: the awkward economics and politics of North American monetary integration, Commentary No. 167, Toronto, C. D. Howe Institute

Rogoff, K. (1996) The purchasing power parity puzzle Jopurnal of Economic Literature 34 (June) 647-668

Summers, L. (1999) Overcoming volatility: Latin America and the IDB, remarks by Lawrence H. Summers, Deputy Secretary of the Treasury, Inter-American Development Bank Annual Meetings, Paris, France , March 15. Treasury News, Washington D.C. US. Treasury

Thiessen, G. (2001) The Thiessen Lectures: Lectures delivered by Gordon G. Thiessen, Governor of the Bank of Canada 1994-2001 Ottawa, Bank of Canada

Thom, R. and Walsh, B. (2002) The effects of a currency union on trade: lessons from the Irish experience, Dublin, University College, mimeo

US Senate, Joint Economic Committee (1999) Encouraging Official Dollarization in emerging Markets, Staff Report, Washington D. C., Office 0f the Chairman, Senator Connie Mack. 


\section{CESifo Working Paper Series}

(for full list see www.cesifo.de.)

702 Ralph Chami and Gregory D. Hess, For Better or For Worse? State-Level Marital Formation and Risk Sharing, April 2002

703 Fredrik Andersson and Kai A. Konrad, Human Capital Investment and Globalization in Extortionary States, April 2002

704 Antonis Adam and Thomas Moutos, The Political Economy of EU Enlargement: Or, Why Japan is not a Candidate Country?, April 2002

705 Daniel Gros and Carsten Hefeker, Common Monetary Policy with Asymmetric Shocks, April 2002

706 Dirk Kiesewetter and Rainer Niemann, Neutral and Equitable Taxation of Pensions as Capital Income, April 2002

707 Robert S. Chirinko, Corporate Taxation, Capital Formation, and the Substitution Elasticity between Labor and Capital, April 2002

708 Frode Meland and Gaute Torsvik, Structural Adjustment and Endogenous Worker Recall Probabilities, April 2002

709 Rainer Niemann and Caren Sureth, Taxation under Uncertainty - Problems of Dynamic Programming and Contingent Claims Analysis in Real Option Theory, April 2002

710 Thomas Moutos and William Scarth, Technical Change and Unemployment: Policy Responses and Distributional Considerations, April 2002

711 Günther Rehme, (Re-)Distribution of Personal Incomes, Education and Economic Performance Across Countries, April 2002

712 Thorvaldur Gylfason and Gylfi Zoega, Inequality and Economic Growth: Do Natural Resources Matter?, April 2002

713 Wolfgang Leininger, Contests over Public Goods: Evolutionary Stability and the FreeRider Problem, April 2002

714 Ernst Fehr and Armin Falk, Psychological Foundations of Incentives, April 2002

715 Giorgio Brunello, Maria Laura Parisi, and Daniela Sonedda, Labor Taxes and Wages: Evidence from Italy, May 2002

716 Marta Aloi and Huw Dixon, Entry Dynamics, Capacity Utilisation and Productivity in a Dynamic Open Economy, May 2002 
717 Paolo M. Panteghini, Asymmetric Taxation under Incremental and Sequential Investment, May 2002

718 Ben J. Heijdra, Christian Keuschnigg, and Wilhelm Kohler, Eastern Enlargement of the EU: Jobs, Investment and Welfare in Present Member Countries, May 2002

719 Tapio Palokangas, The Political Economy of Collective Bargaining, May 2002

720 Gilles Saint-Paul, Some Evolutionary Foundations for Price Level Rigidity, May 2002

721 Giorgio Brunello and Daniela Sonedda, Labor Tax Progressivity, Wage Determination, and the Relative Wage Effect, May 2002

722 Eric van Damme, The Dutch UMTS-Auction, May 2002

723 Paolo M. Panteghini, Endogenous Timing and the Taxation of Discrete Investment Choices, May 2002

724 Achim Wambach, Collusion in Beauty Contests, May 2002

725 Dominique Demougin and Claude Fluet, Preponderance of Evidence, May 2002

726 Gilles Saint-Paul, Growth Effects of Non Proprietary Innovation, May 2002

727 Subir Bose, Gerhard O. Orosel, and Lise Vesterlund, Optimal Pricing and Endogenous Herding, May 2002

728 Erik Leertouwer and Jakob de Haan, How to Use Indicators for 'Corporatism' in Empirical Applications, May 2002

729 Matthias Wrede, Small States, Large Unitary States and Federations, May 2002

730 Christian Schultz, Transparency and Tacit Collusion in a Differentiated Market, May 2002

731 Volker Grossmann, Income Inequality, Voting Over the Size of Public Consumption, and Growth, May 2002

$732 \mathrm{Yu}-\mathrm{Fu}$ Chen and Michael Funke, Working Time and Employment under Uncertainty, May 2002

733 Kjell Erik Lommerud, Odd Rune Straume, and Lars Sørgard, Downstream Merger with Oligopolistic Input Suppliers, May 2002

734 Saku Aura, Does the Balance of Power Within a Family Matter? The Case of the Retirement Equity Act, May 2002

735 Sandro Brusco and Fausto Panunzi, Reallocation of Corporate Resources and Managerial Incentives in Internal Capital Markets, May 2002 
736 Stefan Napel and Mika Widgrén, Strategic Power Revisited, May 2002

737 Martin W. Cripps, Godfrey Keller, and Sven Rady, Strategic Experimentation: The Case of Poisson Bandits, May 2002

738 Pierre André Chiappori and Bernard Salanié, Testing Contract Theory: A Survey of Some Recent Work, June 2002

739 Robert J. Gary-Bobo and Sophie Larribeau, A Structural Econometric Model of Price Discrimination in the Mortgage Lending Industry, June 2002

740 Laurent Linnemer, When Backward Integration by a Dominant Firm Improves Welfare, June 2002

741 Gebhard Kirchgässner and Friedrich Schneider, On the Political Economy of Environmental Policy, June 2002

742 Christian Keuschnigg and Soren Bo Nielsen, Start-ups, Venture Capitalits, and the Capital Gains Tax, June 2002

743 Robert Fenge, Silke Uebelmesser, and Martin Werding, Second-best Properties of Implicit Social Security Taxes: Theory and Evidence, June 2002

744 Wendell Fleming and Jerome Stein, Stochastic Optimal Control, International Finance and Debt, June 2002

745 Gene M. Grossman, The Distribution of Talent and the Pattern and Consequences of International Trade, June 2002

746 Oleksiy Ivaschenko, Growth and Inequality: Evidence from Transitional Economies, June 2002

747 Burkhard Heer, Should Unemployment Benefits be Related to Previous Earnings?, July 2002

748 Bas van Aarle, Giovanni Di Bartolomeo, Jacob Engwerda, and Joseph Plasmans, Staying Together or Breaking Apart: Policy-makers' Endogenous Coalitions Formation in the European Economic and Monetary Union, July 2002

749 Hans Gersbach, Democratic Mechanisms: Double Majority Rules and Flexible Agenda Costs, July 2002

750 Bruno S. Frey and Stephan Meier, Pro-Social Behavior, Reciprocity or Both?, July 2002

751 Jonas Agell and Helge Bennmarker, Wage Policy and Endogenous Wage Rigidity: A Representative View From the Inside, July 2002

752 Edward Castronova, On Virtual Economies, July 2002

753 Rebecca M. Blank, U.S. Welfare Reform: What's Relevant for Europe?, July 2002

754 Ruslan Lukach and Joseph Plasmans, Measuring Knowledge Spillovers Using Patent Citations: Evidence from the Belgian Firm's Data, July 2002 
755 Aaron Tornell and Frank Westermann, Boom-Bust Cycles in Middle Income Countries: Facts and Explanation, July 2002

756 Jan K. Brueckner, Internalization of Airport Congestion: A Network Analysis, July 2002

757 Lawrence M. Kahn, The Impact of Wage-Setting Institutions on the Incidence of Public Employment in the OECD: 1960-98, July 2002

758 Sijbren Cnossen, Tax Policy in the European Union, August 2002

759 Chandima Mendis, External Shocks and Banking Crises in Developing Countries: Does the Exchange Rate Regime Matter?, August 2002

760 Bruno S. Frey and Lars P. Feld, Deterrence and Morale in Taxation: An Empirical Analysis, August 2002

761 Lars Calmfors and Åsa Johansson, Nominal Wage Flexibility, Wage Indexation and Monetary Union, August 2002

762 Alexander R. W. Robson and Stergios Skaperdas, Costly Enforcement of Property Rights and the Coase Theorem, August 2002

763 Horst Raff, Preferential Trade Agreements and Tax Competition for Foreign Direct Investment, August 2002

764 Alex Cukierman and V. Anton Muscatelli, Do Central Banks have Precautionary Demands for Expansions and for Price Stability? - Theory and Evidence, August 2002

765 Giovanni Peri, Knowledge Flows and Knowledge Externalities, August 2002

766 Daniel Friedman and Nirvikar Singh, Equilibrium Vengeance, August 2002

767 Sam Bucovetsky and Michael Smart, The Efficiency Consequences of Local Revenue Equalization: Tax Competition and Tax Distortions, August 2002

768 Tapio Palokangas, International Labour Market Regulation and Economic Growth with Creative Destruction, August 2002

769 Rudi Dornbusch, The New International Architecture, September 2002

770 Hans-Werner Sinn, Weber's Law and the Biological Evolution of Risk Preferences: The Selective Dominance of the Logarithmic Utility Function, September 2002

771 Thomas Mayer, The Macroeconomic Loss Function: A Critical Note, September 2002

772 Seppo Honkapohja and Kaushik Mitra, Learning Stability in Economies with Heterogenous Agents, September 2002

773 David Laidler, Inflation Targets Versus International Monetary Integration - A Canadian Perspective, September 2002 